
the Creative Commons Attribution licence (http://creativecommons.org/licenses/by/4.0/), which permits unrestricted reuse, distribution and reproduction in any medium, provided the original work is properly cited.

\title{
ATTALID AESTHETICS: THE PERGAMENE 'BAROQUE’ RECONSIDERED
}

\author{
THOMAS J. NELSON \\ Corpus Christi College, University of Cambridge*
}

\begin{abstract}
In this paper, I explore the literary aesthetics of Attalid Pergamon, one of the Ptolemies' fiercest cultural rivals in the Hellenistic period. Traditionally, scholars have reconstructed Pergamene poetry from the city's grand and monumental sculptural programme, hypothesizing an underlying aesthetic dichotomy between the two kingdoms: Alexandrian 'refinement' versus the Pergamene 'baroque'. In this paper, I critically reassess this view by exploring surviving scraps of Pergamene poetry: an inscribed encomiastic epigram celebrating the Olympic victory of a certain Attalus (IvP I.10) and an inscribed dedicatory epigram featuring a speaking Satyr ( $S G O$ I.06/02/05). By examining these poems' sophisticated engagements with the literary past and contemporary scholarship, I challenge the idea of a simple opposition between the two kingdoms. In reality, the art and literature of both political centres display a similar capacity to embrace both the refined and the baroque. In conclusion, I ask how this analysis affects our interpretation of the broader aesthetic landscape of the Hellenistic era and suggest that the literature of both capitals belongs to a larger system of elite poetry which stretched far and wide across the Hellenistic world.
\end{abstract}

Keywords: Pergamon, Attalids, aesthetics, baroque, Alexandria

\section{An alternative aesthetic?}

Whatever the rhetoric of Ptolemaic kingship might have us think, the Ptolemies were far from the only Hellenistic monarchy to patronize literary culture and the arts. Every Hellenistic kingdom we know of placed a strong premium on poetry and learning, which were essential marks of not only Hellenic identity but also royal power and authority. Recent scholarship has effectively highlighted how the Seleucid kings articulated and propagated their imperial visions through court literature, ${ }^{1}$ while the Antigonids too profited from their own patronage of poets and scholars. ${ }^{2}$ In this paper, however, I intend to focus on the literary dynamics of another kingdom - that of the Attalids, whose efforts to fashion a new home of the Muses at Pergamon cast themselves as the fiercest cultural rivals to the Ptolemies. Not only did Eumenes II found a library to contend with that of Alexandria (complete with its own set of Pinakes), ${ }^{3}$ but the Attalid kings also patronized and supported a whole host of poets, scholars and other intellectuals. ${ }^{4}$ According to the anecdotal tradition, the rivalry ran so deep that Ptolemy $\mathrm{V}$ even resorted to imprisoning Aristophanes of Byzantium and banning the export of papyrus to inhibit his rivals' project. ${ }^{5}$ Despite their humble

*tjn28@cam.ac.uk. I am grateful to audiences in Edinburgh and Cambridge for improving feedback on earlier versions of this paper. Particular thanks are due to those who commented on written drafts: Maria Broggiato, Alex Forte, Richard Hunter, Max Leventhal, the editor and referees of JHS and especially Aneurin EllisEvans, who made me think far harder about historical context. The project was supported by the Golden Web Foundation and the Arts and Humanities Research Council. Translations are my own, unless otherwise indicated.

1 Primo (2009); Barbantani (2014); Kosmin (2014) especially 31-76; (2018) especially 87-88; Visscher (2019); (2020); Nelson (forthcoming d).

2 See, for example, Aratus' cis 'Avtíyovov ( $\mathrm{SH} 99)$ and the alternative proem of his Phaenomena (Avtífove,

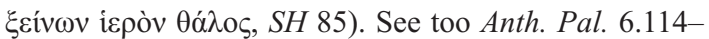
16, three epigrams about Philip V's dedication to his ancestor Heracles (Edson (1934)).

3 Library: Strabo 13.4.2; Mielsch (1995); Nagy (1998); Coqueugniot (2013). Eumenes may simply have expanded a pre-existing library founded by his father Attalus I (Müller (1989) 538; Kosmetatou (2003) 164). A story in Vitruvius holds that the Attalids invented libraries before the Ptolemies (De arch. 7, pref. 4), but this seems ascribable to pro-Attalid propaganda (Romano

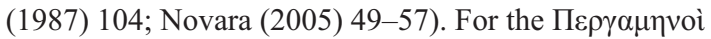

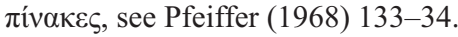

${ }^{4}$ For the Attalids' literary culture and patronage, see Hansen (1971) 390-433; Barbantani (2001) 181-83.

5 Ptolemy locked up Aristophanes because he was afraid that he wanted to desert to Eumenes II (Suda o 
origins and late rise to power, the Attalids were not content to play second fiddle to their major rivals when it came to cultural politics. ${ }^{6}$

The situation of our evidence at Pergamon, however, is almost the exact opposite of that in Alexandria: while we are blessed with a rich archaeological record, we have paltry literary remains, rendering the Attalids' once active and flourishing literary climate almost fully obscured. Scholars have attempted to overcome this obstacle in various ways: some have unearthed potential hints of an Attalid connection in extant Hellenistic texts, reading a celebration of Roman-Pergamene relations into Lycophron's Alexandra or a reflection of Attalus III's interest in animals and poisons into Nicander's Theriaca $;^{7}$ others have mined later literary works, such as Philostratus' Heroicus and Tzetzes' Antehomerica, for potential reflections of putative Pergamene poems on Telephus; ${ }^{8}$ while others still have turned to Pergamene art as a blueprint to reconstruct Attalid literature, imagining great baroque epics to parallel the grandeur of the Pergamene Great Altar's Gigantomachy. ${ }^{9}$

Such reconstructions, however, can only ever get us so far, and they should often be taken with a healthy serving of scepticism. In particular, the concoction of gigantomachic epics from the Altar requires considerable caution, as Marco Fantuzzi and Alan Cameron have warned. ${ }^{10}$ Yet even so, the assumed parallel between art and literature that underlies these efforts continues to linger in the scholarly imagination and informs the common assumption that Pergamene aesthetics are somehow diametrically opposed to those of Alexandria: the baroque nature of much Pergamene art is regarded as a stark contrast to the refined and delicate ideals of Alexandrian poets. ${ }^{11}$ In a recent formulation of this opposition, Kathryn Gutzwiller has remarked that the Attalids' 'sculptural program, with its themes of cosmic strife and human suffering, acts as a counterweight to the more subtle and personal themes characteristic of Alexandrian tastes. A rivalry between Pergamum and the Ptolemaic court, in scholarship, literature, and art, seems by the second century to have coalesced into somewhat different aesthetic standards, and the tension between them continued to shape the Roman adaptation of Hellenistic culture. ${ }^{12}$ On the face of it, Pergamon thus seems to present an alternative aesthetic to that of Callimachus and Alexandria, offering a potential glimpse into one of the marginalized literary voices of the Hellenistic era.

However, this common viewpoint requires a critical reassessment. There is no doubt that there were manifest scholarly differences between the two kingdoms: Crates' Pergamene school of allegorical interpretation had a different emphasis to Aristarchus' far more philological method in Alexandria, and followers of each camp did not hesitate from writing polemical treatises against each other. ${ }^{13}$ Yet even here we should be wary of exaggerating these methodological differences, as David Blank has highlighted. ${ }^{14}$ When we set such scholarly polemic aside, moreover, it is far less clear that these oppositions extended to the spheres of literature and art more generally, espe-

3936; Pfeiffer (1968) 172; Fraser (1972) 1.461). Papyrus: Plin. $H N$ 13.70, part of a larger aetiology of Pergamene parchment (Johnson (1970)).

${ }^{6}$ On the Attalids' origins and cultural politics more generally, see especially Schalles (1985); Gruen (2000).

7 Lycophron's Alexandra: Kosmetatou (2000); Looijenga (2014) 236-37; criticized by Hornblower (2015) 48-49; (2018) 18-19. Nicander's Theriaca: Touwaide (1991) 96-97; Massimilla (2000) 136; Magnelli (2010) 212; $c f$. too Jacques (2006) 27-28 on Nicander's Georgica.

8 Philostr. Her. 23; Tzetz. Antehom. 268-85; cf. Robert (1887) especially 255-59; Brückner (1904); Hansen (1971) 408-09; Hardie (1986) 138-39. These narratives overlap significantly with the Telephus frieze of the Great Altar (Rusten and König (2014) 57).

${ }^{9}$ Ziegler (1966) 43-52 = (1988) 50-61; echoed by
Zanker (1983) 136; Hardie (1986) 127-28; Bing (1988) 50; Stewart (2006) 128.

${ }^{10}$ Fantuzzi (1988) 1-liii; Cameron (1995) 282. On the limited and miniaturizing treatment of giants in extant Hellenistic poetry, see Prioux (2017).

11 On the Hellenistic baroque, which is by no means simple to define, see Pollitt (1986) 111-26; Stewart (1993) 133-37; (2006); Schultz (2011).

12 Gutzwiller (2007) 15-16.

13 See Düring (1941) 9-11; Pfeiffer (1968) 234-51; Porter (1992). On the Pergamene 'Cratetean school', see especially the work of Broggiato on Crates (2001), Zenodotus (2005) and others (2014).

${ }^{14}$ Blank (2005), challenging the perceived dichotomy between Alexandrian 'analogy' and Cratetean 'anomaly'; $c f$. too Broggiato (2001) xxxv, xxxviii-xxxix. For a recent reappraisal, see Matthaios (2018). 
cially once we stop comparing Ptolemaic poetry so directly with Pergamene sculpture - a serious mismatch of media. Instead, we should do all we can to compare like with like: poetry with poetry, and art with art. Only then can we gain a fuller understanding of each kingdom's aesthetic preferences. ${ }^{15}$

In this paper, I intend to focus on the poetic side of the equation, exploring several scraps of extant Pergamene poetry: one epinician and one dedicatory epigram, both of which explicitly mention an Attalus by name. They are thus both firmly rooted in a Pergamene context, at the crossroads between politics and art, offering a useful test case for asking both if and how political and geographical differences influenced Hellenistic literary aesthetics. The authorship of these poems is unknown, so we are unable to determine whether they were produced by native Pergamenes, imported court poets or itinerant bards. But regardless of their authors' identities, these works offer insight into the kind of literature patronized by and produced for the Attalid kings, and it is this secure Attalid context which I refer to when I describe these poems and their poets as 'Pergamene'. ${ }^{16}$ After subjecting each epigram to a detailed analysis, I will conclude by asking how these texts affect our interpretation of the broader aesthetic landscape of the Hellenistic world and the alleged opposition between Alexandrian refinement and the Pergamene baroque.

\section{Allusive athletics: an Attalid epinician epigram}

The first poem I would like to explore is an epinician epigram which extols the Olympic victory of an unspecified Attalus. Sporting success at the Panhellenic games was an integral part of any Hellenistic ruler's self-fashioning: a sign of strength, wealth and Greekness. And we know that the Pergamene kings, like their rivals, won a great number of equestrian victories, including a whole string at the Panathenaic games which they commemorated monumentally in sculptural form at Athens. ${ }^{17}$ We also have at least one other extant epinician epigram for an Attalid victory at Olympia: a four-verse poem by Arcesilaus of Pitane, head of the Academy in Athens and friend of the Pergamene royal house $\left(S H 121=1\right.$ Page, FGE 55-58). ${ }^{18}$ Athletic success and its celebration were clearly very important for the Attalids, and this anonymous epigram would have played a key role in conveying this to a Pergamene audience $\left(I v P\right.$ I.10 $=S G O$ I.06/02/21): ${ }^{19}$

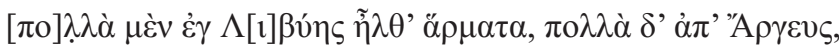
$[\pi \mathrm{o}] \lambda \lambda \dot{\alpha} \delta \dot{\varepsilon} \pi[1] \varepsilon \dot{\rho} \rho \varsigma_{\varsigma} \tilde{\eta} \lambda \theta^{\prime}$ à $\pi$ ò $\Theta \varepsilon \sigma \sigma \alpha \lambda i ́ \eta \varsigma$,

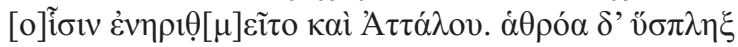

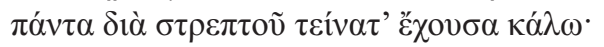

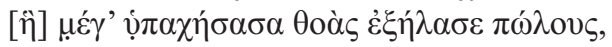

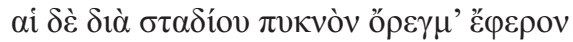

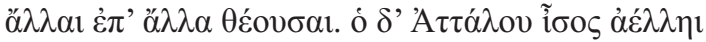

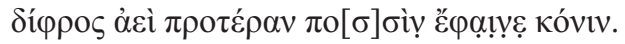

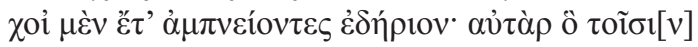

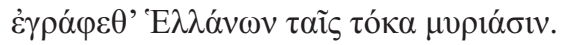

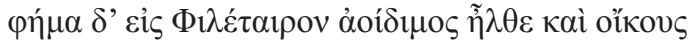

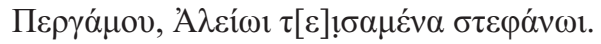

15 For recent explorations of Hellenistic aesthetics in art and literature that are more attuned to variation between different media, see Prioux (2007); Squire (2011); Linant de Bellefonds and Prioux (2018).

${ }_{16}$ Notably, all the major 'Ptolemaic' poets came from or were associated with other places beyond Alexandria: Callimachus and Cyrene, Apollonius and Rhodes, Posidippus and Macedonian Pella, Theocritus and Syracuse (Willi (2012)). Their extra-Egyptian affili-

ations do not prevent us from calling them 'Alexandrian' poets (see, for example, Stephens (2018)).

17 See Queyrel (2003) 307-08.

18 On this poem, see von der Mühll (1956) 717-20; Page (1981) 18-19; Cameron (1995) 201-02; Barbantani (2012) 44. For epigram as a mode of panegyric, see Coleman (2019) 60-64.

19 Text from Ebert (1972) 176-81, no. 59; cf. too Moretti (1953) 94-99, no. 37. 
Many chariots came from Libya, many from Argos and many came from rich Thessaly, among which was also numbered that of Attalus. The starting line tensed, holding them all together with its twisted rope. With a loudly echoing clap, it then drove out the quick colts, who bore a swift stride through the racecourse, some running behind some chariots, others behind others. But Attalus' chariot-team, like a whirlwind, constantly kicked up the frontmost dust with their feet. The other teams still competed on, snorting deeply, but among them his team made its mark on the tens of thousands of Greeks who were then present. The fame of song came to Philetaerus and the houses of Pergamon, honouring them with the crown of Elis.

This epigram was inscribed on a marble block found under the southwestern corner of the Pergamene Athena sanctuary, where it must once have formed part of an equestrian victory monument. The badly damaged inscription of a second block reveals another epinician epigram, presumably for the same or a similar victory (IvP I.11), ${ }^{20}$ while a third block of similar shape and size is inscribed with the name of Epigonus, a prominent Pergamene artist who was also involved in the Attalids' Galatian dedications. ${ }^{21}$ This final inscription dates from a later monument of around 190 $\mathrm{BC}$, in which the first two blocks had been reused, so we cannot certainly identify Epigonus as the sculptor of the original equestrian statuary. ${ }^{22}$ But it is nevertheless clear that this epigram once belonged to a multimedia monument, combining text and image to glorify the achievements of the victorious Attalus.

The letter forms of the inscription suggest a date in the first half of the third century $\mathrm{BC},{ }^{23}$ and, given the direct mention of Philetaerus (the founder of the Attalid dynasty) in the penultimate line, the victory must have occurred during his reign. ${ }^{24}$ This means that the laudandus in question is most likely his nephew and adopted son Attalus, the father of the future Attalus I. ${ }^{25}$ The victory thus dates from a time before the Attalid dynasty had become a royal kingdom (only after defeating the Galatians in the 230s BC did Attalus I adopt the royal diadem) ${ }^{26}$ and before it had even faced its first succession of power (a future event which must already have been a subject of considerable thought and concern). Even at this early stage, however, the epigram provides substantial evidence for the family's growing cultural pretensions. In the discussion that follows, we shall see not only how the poem rivals the literary sophistication of Alexandrian texts but also how it already exhibits key concerns that would later prove emblematic of Attalid kingship, including the display of familial harmony and the legitimization of their Greek rule in Asia Minor through mythological precedent. We may wonder, indeed, whether these aspects of Pergamene ideology were being formulated precisely at this very moment in response to the impending first transferral of power - at a time when the establishment of an enduring dynasty was most uncertain. ${ }^{27}$

20 Verbal parallels between the two epigrams suggest that they formed an interrelated diptych: $\tilde{\eta} \lambda \theta \underline{\varepsilon}(11.1) \sim$

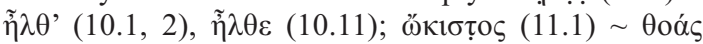

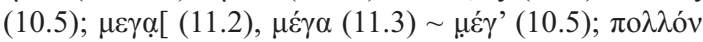

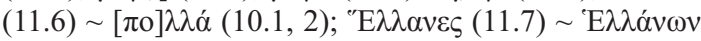
(10.10); 'A $\tau \tau \alpha \lambda \circ v$ (11.8) A $\tau \tau \alpha \dot{\lambda} \mathrm{ov}(10.3,10.7)$.

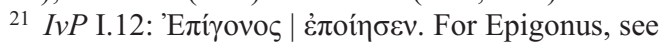
Plin. HN 34.88; Schober (1938); Hansen (1971) 301-02.

22 Kähler (1948) 187-89 n.47; cf. Schober (1951) 51 n.17; Schalles (1985) 44 n.293; Hansen (1971) 27 n.4.

23 Ebert (1972) 176.

24 Philetaerus reigned 282-263 BC. Another victor in the four-team colt chariot race is already known for 268 BC (Belistiche: P.Oxy. 2082; Moretti (1957) 13637 , no. 549), which leaves $280,276,272$ or 264 BC (thus Ebert (1972) 177). The final date, $264 \mathrm{BC}$, is unlikely because of the ongoing Chremonidean War and because
Attalus was probably already dead by then (Moretti (1953) 98; von der Mühll (1956) 719; Schalles (1985) 44 n.293).

25 Thus Fränkel (1890) 8; von der Mühll (1956) 719; Ebert (1972) 176; Schalles (1985) 44. Barbantani (2012) 44 proposes the young Attalus I himself, but - as earlier scholars have noted - he would have only been a young child, rendering his involvement unlikely.

${ }^{26}$ Strabo 13.4.2; Polyb. 18.41; cf. Hansen (1971) 26-33; Allen (1983) 28-35; Chrubasik (2013) 95-96. For Attalid and other kings' victory celebrations over the Galatians, see Nelson (forthcoming a).

27 I thank Aneurin Ellis-Evans for encouraging me to dwell on the significance of this pivotal moment in the development of the dynasty, comparing the anxiety of succession felt in the major Hellenistic kingdoms a decade or so earlier. 
At first glance, however, this epigram might seem a bad choice to test the sophistication and complexity of Pergamene poetry. The text's original editor, Max Fränkel, judged from its simple syntax and spattering of local dialectal forms that this was the work of a mere 'Versifex', a poem that can 'only give us a very slight idea of Pergamene court poets' abilities' ${ }^{28} \mathrm{~A}$ closer examination, however, reveals that this epigram is an elaborately erudite composition, a poem that can tell us far more about Pergamene court poetry than Fränkel thought. ${ }^{29}$ Indeed, even the features he maligned have a demonstrable artistic function. The simple syntax and accumulation of brief clauses lend a sense of growing excitement as events rapidly accelerate to the victorious climax a sense also reinforced by the poet's exploitation of metre: the sequence of five consecutive dactyls in verse seven aptly mimics the speed and jostling of the chariots. The Doric dialectal elements, meanwhile, resonate pointedly against the conventional classicizing language of Attalid decrees, evoking both the Doric associations of Macedonian royalty and the linguistic strains of epinician choral lyric; they hint at Attalus' monarchic pretensions and the epigram's literary heritage. ${ }^{30}$

Other elements reinforce this sense of a refined composition. In addition to several verbal rarities,${ }^{31}$ the epigram exhibits an attractively symmetrical structure. Besides its balanced tripartite division (1-4 preparation, 5-8 race, 9-12 victory and celebration), it offers a neat ring composition of competitors coming to Olympia ( $\tilde{\hat{\eta}} \lambda \theta^{\prime}$, vv. 1,2$)$ and the fame of the Olympian crown coming back to Pergamon $(\tilde{\eta} \lambda \theta \varepsilon$, v. 11). In its metrics, it features a modern sensibility: four out of the six pentameters display the common Hellenistic penchant for placing an adjective and its associated noun at the end of each half line. ${ }^{32}$ And more self-consciously, the poem even seems to play with its inscribed epigrammatic status: the closing metaphorical image of Attalus' team 'engraved' in the minds of the Greek audience ('่ $\gamma \rho \alpha{ }^{\prime} \varphi \varepsilon \theta$ ', v. 10) recalls the very context of this epigram which is itself 'engraved' on stone. ${ }^{33}$ The complementarity of immediate and later reception implies that this epigram's words can capture something of the original event. ${ }^{34}$

This epigram is thus a literary artefact that has been wrought with much care. But such sophistication is also manifest in the poem's allusions to earlier Archaic and Classical texts. Amid its dense array of echoes, past scholars have especially highlighted its connections with the false messenger speech of Sophocles' Electra, an oration that describes Orestes' alleged 'death' in a Pythian chariot race (El. 680-763) ${ }^{35}$ In particular, the parallels cluster around that narrative's initial scene setting (El. 698-719):

${ }^{28}$ Fränkel (1890) 9: 'Unser Gedicht kann von der Fähigkeit der pergamenischen Hofpoeten nur eine sehr geringe Vorstellung erwecken.' See, for example, the elementary syntax of verse 11 and dialectal forms like

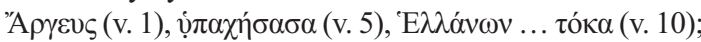

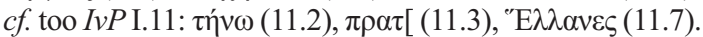

${ }^{29}$ Other scholars have offered similarly favourable assessments, but rarely with much justification for their judgement: the poet is 'alles andere als ein Dilettant' (Ebert (1972) 179); the poem is 'un bell'epigramma' (Moretti (1957) 135, no. 538); an 'elaborate epigram' of a 'competent poet' (Cameron (1995) 286); an 'ambitious victory epigram' (van Bremen (2007) 346); and 'of high literary quality' (Barbantani (2012) 43).

${ }^{30}$ On the language of Pergamene inscriptions, see Schweizer (1898); Bubeník (1989) 244. See also Coughlan (2016) on the allusive significance of dialect in epigram, and both Sens (2004) 73-75 and Fantuzzi and Hunter (2004) 371-77 for the Doric association of Macedonian royalty.

31 For example, the rare and largely poetic noun ö $\rho \xi \gamma \mu \alpha$ (v. 6), also used by Theocritus' friend Nicias (8.4 Gow-Page, HE $2786=$ Anth. Plan. 189.4), and the variant spelling of the aorist middle of $\tau i ́ \omega(\tau[\varepsilon] 1 \sigma \alpha \mu \varepsilon \dot{v} v \alpha$, v. 12, preferring Peek and Wilhelm's emendation to Schuchardt's $\tau[\varepsilon \lambda] \sigma \alpha \mu \varepsilon \dot{v} \alpha$ ), which is only paralleled by the future form $\tau \varepsilon i ́ \sigma o \mu \varepsilon v$ used by the Alexandrian poet Philicus of Corcyra ( $\mathrm{SH}$ 680.42).

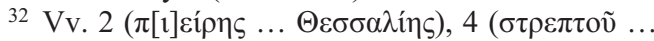

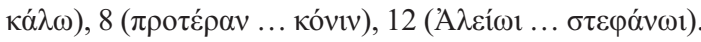

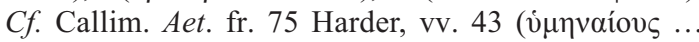

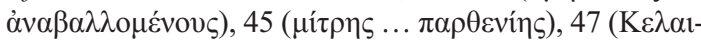

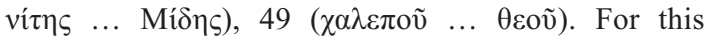
Hellenistic feature of versification, see Slings (1993) 3334, 37; Hutchinson (2016).

${ }^{33}$ For this metaphorical sense of the verb, Ebert

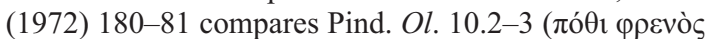

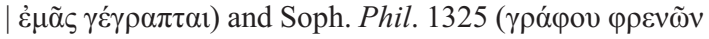
$\varepsilon \sigma \omega)$. Given the absence of further words clarifying the metaphor in our epigram, his $\dot{\varepsilon} \gamma<\gamma>\rho \alpha \dot{\varphi} \varphi \varepsilon \theta^{\prime}$ may well be right; the inscribed text could be explained as a simple case of haplography.

${ }^{34}$ For a similarly 'self-referential nod' elsewhere in

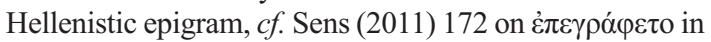
Asclepiades 25 Gow-Page, HE 920-31 = Anth. Pal. 5.181.

35 For example, von der Mühll (1956) 718: the poem 


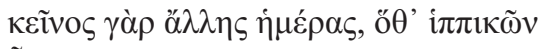

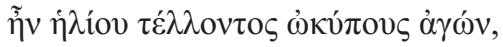
$\varepsilon \dot{i} \sigma \tilde{\eta} \lambda \theta \varepsilon \pi \mathrm{o} \lambda \lambda \tilde{\omega} v \dot{\alpha} \rho \mu \alpha \tau \eta \lambda \alpha \tau \tilde{\omega} v \mu \varepsilon \dot{\tau} \alpha$.

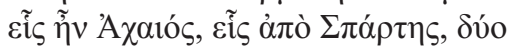
$\Lambda i \beta$

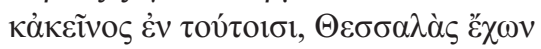

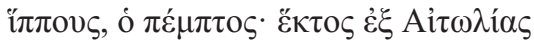

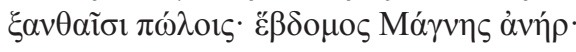

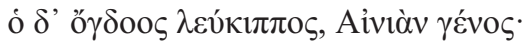

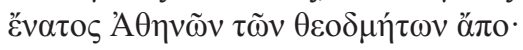

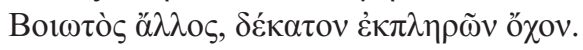

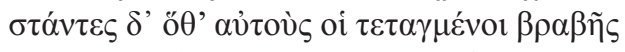

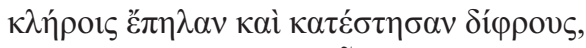

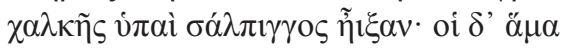

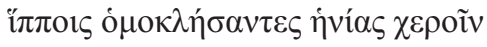

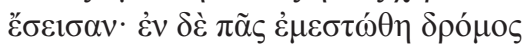

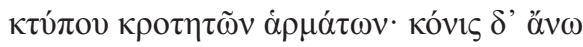


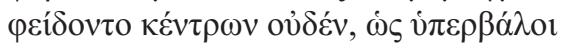

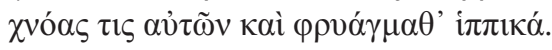

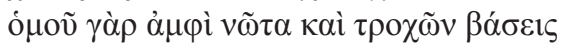

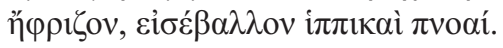

For on another day, when at sunrise there was the speedy contest of the chariot horses, he entered the lists with many charioteers. One was an Achaean, one from Sparta, two were Libyans, masters of yoked cars, and he too was among them with Thessalian mares, the fifth; the sixth came from Aetolia, with chestnut colts; the seventh was Magnesian; the eighth had white horses, an Aenian; the ninth came from Athens, built by gods; another was Boeotian, filling the tenth chariot. They took their stand where the appointed judges had sorted them with lots and placed their chariots, and at the sound of the brazen trumpet darted off. Shouting to their horses, the drivers gripped the reins and shook them loose; the whole course resounded with the clash of rattling chariots; the dust rose up; and all close together, they did not spare the use of their goads, each hoping to pass the wheels and the snorting horses of the others; for about their backs and their wheels below alike the breath of the horses touched them with its foam. ${ }^{36}$

This passage shares numerous parallels of language, style and structure with our Pergamene epigram. Both texts begin with a catalogue of unnamed competitors identified by ethnicity and both include contestants from Libya (v. $1 \sim E l$. 702), Thessaly (v. $2 \sim E l$. 703; cf. Magnesia, El. 705) and areas of the Peloponnese (Argos, v. $1 \sim$ Achaea and Sparta, El. 701). ${ }^{37}$ The protagonist of each is introduced at the same point in the sequence (in the third line of the list, as the fourth nationality) and with the similar idea of being counted among the larger group ([o]ĩolv

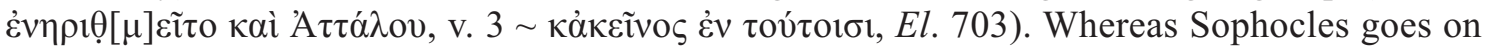
to include ten competitors in total, however, our epigrammatist climatically ends his list with Attalus in priamel-fashion and instead conveys the larger mass of competitors through a three-

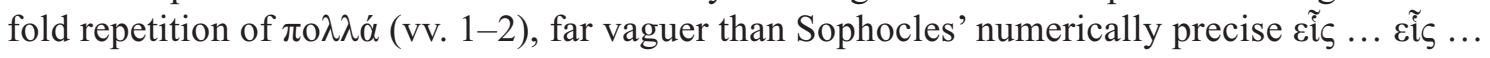
Súo (El. 701).

contains 'eine an Sophokles' Botenbericht in der Elektra erinnernde ... Ausführung des Sieges des Wagens des Attalos'; Ebert (1972) 179: the Sophoclean messengerspeech is 'Das große Vorbild'; van Bremen (2007) 366: the epigram 'so obviously takes as its example the description ... of Orestes' fatal chariot race'.

36 Tr. adapted from Lloyd-Jones (1994a) 228-31.

37 All these places were, of course, famous for horses and horse-breeding in antiquity (see Ebert (1972) 179). 
Besides the formation of teams, the details of the Sophoclean race exhibit a number of further similarities. Both texts convey the sudden surge at the start signal (in Sophocles, the trumpet, El. 711 ; in the epigram, the sound of the starting cord falling to the ground, vv. 5-6), alongside the whirling dust (v. $8 \sim E l .714-15$ ), the horses' heavy breath (v. $\sim \sim E l .719$ ) and the general commo-

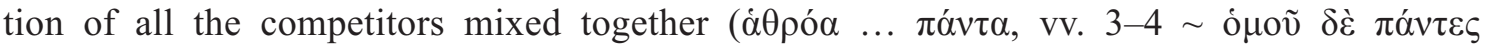
$\dot{\alpha} v \alpha \mu \varepsilon \mu \varepsilon \imath \gamma \mu \varepsilon \dot{\varepsilon} v o 1, E l$. 715). In the ensuing action, both narratives continue to focus on the progress of their protagonist's team (vv. 7-10 El. 720-22, 734-48) and in each case the competing horses

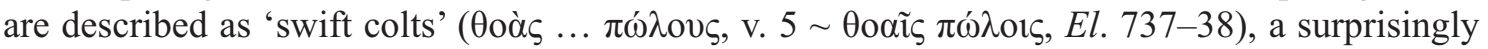
rare collocation. ${ }^{38}$ Although the outcome of each race differs markedly, there are thus many links between the two which suggest that we should bear the Sophoclean scene in mind as we read the epigram. Within a dozen lines, our Pergamene poet captures the bustle and action of the messenger speech, cutting the whole tragic rhēsis down to an epigrammatic scale.

One might object, however, that many of the parallels outlined above are little more than formal and contextual coincidences. Snorting horses and flying dust are set-pieces of chariot-race descriptions from Homer onwards ${ }^{39}$ and many elements of both passages find parallels in epinician lyric more generally. The epigram's opening priamel is a trademark of the genre, ${ }^{40}$ as are descriptions

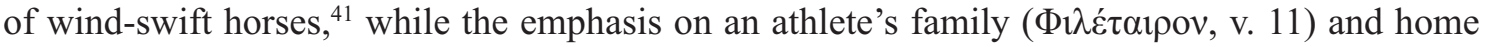

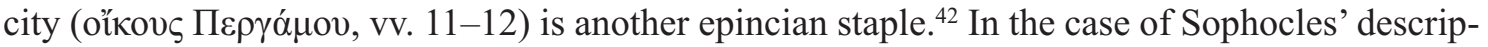
tion, moreover, the very plausibility of the messenger's false speech depends on the poet exploiting as many of the stylized conventions of literary equestrian competitions as possible; the passage is an exemplary imitatio of the genre. ${ }^{43}$ Yet even so, the shared structure and focus of both descriptions set them apart from the mainstream of literary equestrian events. In particular, the detailed treatment of each race's build-up and action (part of what Riet van Bremen calls a 'reportage style') is at odds with the classical epinician tradition, where we almost never find an actual account of the contest itself. ${ }^{44}$ Pindar, in particular, usually shows very little interest in narrating the action of a race, while even Bacchylides, who exhibits a few closer parallels for this 'reportage style', ${ }^{45}$ never offers a comparable treatment of the pre-match line-up. Only in Patroclus' Iliadic funeral games do we find something analogous (Il. 23.287-361), but even there the emphasis is on the individual identities of the competing heroes and the epic histories of their horses (in comparison to the anonymous surveys at El. 701-08 and vv. 1-2 of our epigram), while during the race itself (Il. 23.362-533) the narrator's attention shifts between competitors (rather than staying focused

\footnotetext{
38 Before Gregory of Nazianzus (fourth century AD), the phrase only otherwise appears in v. 1 of Parmenon 1

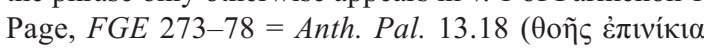
$\pi \dot{\lambda} \lambda \mathrm{ov})$, notably of a colt that dislodges its rider, just as 'Orestes' is thrown off his chariot (El. 746-48); here too, the phrase may allude directly to the Sophoclean messenger speech.

39 Dust: for example, Il. 23.365-66; cf. Hes. Sc. 342 (in a martial context); Bacchyl. 5.44; Simon. $516 P M G$ = 5 Poltera. Horses' breath: Il. 23.380-81; cf. Il. 17.502 (in a martial context).

${ }^{40} \mathrm{Cf}$. especially $\mathrm{Ol}$. $1.1-7$. On priamels in general, see Race (1982).

${ }^{41}$ Epinician horses are often $\alpha \dot{\varepsilon} \lambda \lambda$ ó $\pi \mathrm{o} \delta \varepsilon \varsigma$ (Pind. Pyth. 4.18; Nem. 1.6; fr. 221.1; Simon. $515 P M G=2$ Poltera), like those of the gods (Hom. Hymn 5.217: Tros' horses from Zeus; $c f$. Aeetes' horses from Helios:

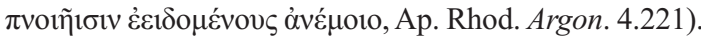

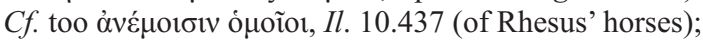

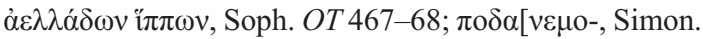
$519 P M G$, fr. $131.2=15.2$ Poltera.
}

42 See van Bremen (2007) 346 on the 'familiar epinikian triad of victor, father, city'.

${ }^{43}$ See Finglass (2007) 301-02 for the speech's literary debts.

44 van Bremen (2007) 367; cf. Lefkowitz (1984) 18; Fuhrer (1993) 93 n.81. Hornblower (2004) 342 n.43 notes this communis opinio, alongside some apparent Pindaric exceptions: Ol. 8.67-69, 9.91-94, 10.72-77; Pyth. 5.49-51, 8.81-87; Nem. 7.72-73. But none of these is at all comparable to the vividness of the epigram or Sophocles' messenger speech.

45 Especially Bacchyl. 5.37-49, 9.27-39, 10.21-28 (see Hadjimichael (2015); (2019) 267-70). Note especially Pherenicus in Ode 5 (thus Ebert (1972) 180): a 'storm-running colt' ( $\pi \tilde{\omega} \lambda$ ov $\alpha \dot{\varepsilon} \lambda \lambda \circ \delta \rho o ́ \mu \alpha \nu, 5.39)$ who runs 'like the blast of the north wind' ( $\dot{\rho} 1 \pi \tilde{\alpha} 1$... í $\sigma \circ \varsigma$

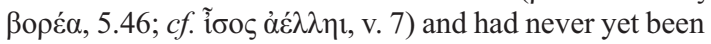
dirtied by the dust of horses ahead of him in the race

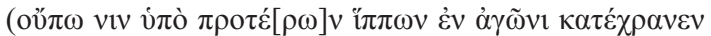
кóvis, 5.43-44; $c f$. v. 8). Another Bacchylidean feature is the personification of $\varphi \eta \dot{\mu} \alpha$ (v. 11): $c f$. Bacchyl. 2.1, 10.1. 
on a single team). Despite the generic epinician backdrop, therefore, the epigram and Sophoclean speech share distinctive features that distinguish them from the standard generic template. The tragic messenger speech stands out as a key intertext for our epigram, augmenting its authority with the kudos of the literary tradition.

Although previous scholars have noted this tragic echo, they have not considered its larger significance for our interpretation of the epigram. What does this literary resonance add to our reading? And why or how does our epigram offer such a 'Conscious, and clever, imitation of a literary model'? ${ }^{46}$ One approach to this question is to treat Sophocles' account as a foil and identify the epigram's divergences from it. We have already noted the additional point gained by recalibrating the competitor list into a climactic priamel centred on Attalus. But we could also add the geographical significance of this reconfiguration: whereas Sophocles first mentions athletes from the Peloponnese, our epigram re-centres the Greek universe away from mainland Greece and starts instead with Libya, a shift that highlights a more diasporic conception of the world in the third century BC. ${ }^{47}$ In addition, the specific choice of Libya, Argos and Thessaly may carry a further political point. All three places evoke major Hellenistic powers: 'Libya' appears repeatedly in Alexandrian poetry as a shorthand for Egypt and even Alexandria; ${ }^{48}$ Argos was closely tied to the Antigonids in the third century and was the homeland of Heracles, the celebrated 'ancestor' of every major Hellenistic monarchy; ${ }^{49}$ and Thessaly had been under Macedonian control since Philip II annexed it in the $350 \mathrm{~s} \mathrm{BC} .{ }^{50}$ At this early date, when Pergamon was still subordinated to the Seleucids, ${ }^{51}$ the choice of these specific opponents suggests that the dynasty was already positioning itself against the major players of the international stage. By foregrounding Attalus' victory over his 'Libyan', 'Argive' and 'Thessalian' competitors, our epigrammatist hints at Pergamon's ability to rival and surpass Ptolemaic Egypt and Antigonid Greece - just as references to Assyria in Alexandrian poetry have been taken as damning dismissals of the Seleucid kings. ${ }^{52}$ In this regard, however, it is significant that the competitor list contains no stand-in for the Seleucids, a notable absence. We could perhaps see this as a reflection of the Attalids' assimilation to a broader Seleucid perspective; as the local representatives of Seleucid power in Asia Minor, the Attalids may have aligned their international viewpoint to that of their masters. Alternatively, however, this Seleucid omission may suggest a more independent and aggressive perspective: even at this early stage, with thoughts of Philetaerus' successor and the future of the dynasty in the background, Pergamon was already looking beyond the Seleucids, glossing over its immediate overlords to position itself against other major international powers. In the epigram's selective choice of Attalus' rivals, we may thus see an early sign of Pergamon's grand aspirations. Whatever the precise nuance of this Seleucid silence, however, it is clear that this rewriting of the Sophoclean competitor list reflects Pergamon's early political posturing during Philetaerus' reign.

Besides such pointed departures, we should also focus on the parallels that these Sophoclean echoes invite us to draw between Attalus and Orestes. It is a striking paradox that Attalus' glorious achievement here is associated with one of the most famous treatments of athletic failure in the literary tradition, ${ }^{53}$ and not just that, but also an account that is itself a complete fiction and fabrication: Attalus' victory is likened to a non-event, hardly the most flattering of comparisons. Set against

46 van Bremen (2007) 366.

${ }^{47}$ A geographical interest is also suggested by the

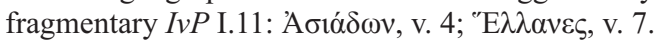

${ }^{48}$ For example, Callim. fr. 228.51 Pf.; Posidippus 116.3 Austin-Bastianini; anon. Anth. Pal. 7.42.5 (which describes Callimachus' 'movement' from Libya to Helicon at the start of the Aetia); cf. Stephens (2003) 181-82; Acosta-Hughes and Stephens (2012) 172 n.69.

49 For Argos' relationship with Antigonid Macedonia, see Tomlinson (1972) 147-63; Gallotta (2016).
On its Heraclean associations, see Scheer (2003) 227.

50 See Graninger (2011) 23-24.

51 For the shifting relationship between the Attalids and Seleucids, see Chrubasik (2013).

52 Cf. Strootman (2010) 35-36; Brumbaugh (2016); Visscher (2017).

53 A problematic resonance: $c f$. Simonides' claim in Xenophon's Hieron that no defeat would be met with so much ridicule as that of a defeated king (Hier. 11.1). 
the backdrop of the Attalid dynasty's much-lauded familial harmony, it must also be troubling for Attalus to be equated with the archetypal mother-killer of myth. ${ }^{54}$ The whole fake messenger speech is, after all, a duplicitous account aimed precisely at furthering and precipitating that matricide. These Sophoclean resonances may thus seem a little out of place in an encomiastic poem.

To my mind, there are at least three ways of interpreting these troubling associations. The first is to downplay them as much as possible. There are a number of significant differences between the situations of Sophocles' Orestes and the victorious Attalus which may minimize the extent of the allusion's disquieting notes: Attalus' victory was at Olympia, not Delphi; his chariot was always at the front of the pack (v. 8), unlike Orestes' more dangerous tactic of hanging back until the end (El. 734-48); ${ }^{55}$ and nobody would expect that Attalus had played an active role in driving the chariot himself - he would never have been in the same danger as Agamemnon's son. In addition, we could highlight positive aspects of the Orestes exemplum that may counteract any negative interpretation: before the chariot accident, Sophocles' Orestes had proved victorious in every other competition (El.681-95), so his otherwise perfect record may still stand as an effective model for Attalid pre-eminence. And more generally, besides the moral complexities of his mother killing, Orestes would have been an excellent analogue for the Attalids, a divinely sponsored and ultimately successful hero who provided a link to the royal families of ancient Greece. ${ }^{56}$ After all, already in the Odyssey the youth stands as a positive paradigm for Telemachus, Odysseus' son, in a treatment of the myth which similarly downplays his vengeful matricide. ${ }^{57}$ As an example closer in time, meanwhile, we could compare the use of the arch-adulterer Helen as a model for Ptolemaic queens in Alexandrian poetry, especially in Theocritus' Idyll 18. As Richard Hunter has remarked, that poem demands 'a process of selective memory' from its audience, 'a continual ignoring of "meaning" which would cause interference or disturbance' ${ }^{58}$ The same cognitive dissonance may also underlie our epigram's Sophoclean allusion. Distant myth, it seems, could provide a malleable set of paradigms for royal encomia, omitting and ignoring the frequently uncomfortable elements of a story to focus on its positive connotations.

However, such an explanation alone is not particularly satisfying, and it is unlikely that every reader of the epigram would have wilfully forgotten the disturbing elements of Orestes' mythical past. A second approach, therefore, would be to embrace the tensions of the allusion and see in them an implicit undermining of Attalid achievement. While ostensibly invoking a notable mythical prototype for Attalus' success, the deeper resonances of the allusion tarnish the lustre of the athletic victory. In that case, the epigram might even foreshadow the polyvalent and ambiguous 'further voices' that haunt various passages of Roman poetry, especially Virgil's Aeneid: Orestes' fictitious downfall subtly undermines the sincerity of epigrammatic praise. ${ }^{59}$

54 On Attalid family harmony, see Kosmetatou (2003) 168-69; Mirón (2018); Nelson (2020) with nn. 26-29. It is more visible later in the dynasty (especially in the filial piety shown towards Apollonis), but already manifest in Philetaerus' close association with his (adopted) sons: for example, they are honoured together in Delphi (FD III.1.432). Athletics itself is a good sphere for asserting family continuity: see Pomeroy (1997) 8595 and the multigenerational claims of Posidippus 78 Austin-Bastianini.

55 The epigram is exceptional in omitting mention of the turning-post (contrast its prominence in $\mathrm{Il} .23$ and $E l$.), thereby defusing the risks associated with chariot racing. The idea of rotational movement introduced by $\dot{\alpha} \varepsilon \dot{\delta} \lambda \eta \uparrow$ at the very mid-point (metaphorical 'turningpoint') of the poem may self-consciously advertise this omission. I thank Alex Forte (personal communication) for this point.

${ }^{56}$ On the positive prestige that later communities drew from Orestes, compare the story of Sparta's acquisition of his bones in the sixth century BC (Hdt. 1.6768; Paus. 3.3.6, 3.11.10; Patterson (2010) 40-42).

${ }^{57}$ For example, Od. 1.298-302, 3.193-200, 3.303316. Cf. Katz (1991) 29-53; Marks (2008) 17-35, especially 30-32; Alden (2017) 77-100.

58 Hunter (1996) 166, see also 164-66 for ironic readings of $I d$. 18. For Helen and Ptolemaic queens more generally, see Acosta-Hughes (2015). Cf. too Buxton (1994) 197 on the moral complexity of mythical exemplarity.

${ }^{59} C f$. Lyne (1987). For a recent review of the 'Harvard' school of pessimistic criticism, see Classical World 111.1 (2017). 
However, here too, such a polar dichotomy of sincere and insincere praise is equally unsatisfying. It is difficult to see the Sophoclean echo completely offsetting the explicit panegyric that underlies the poem, and it would be hazardous to assume that none of the Attalids or their loyal 'friends' was cultured enough to spot such intentional but implicit criticism. A third and more productive interpretation is thus to consider the allusion within the generic context of epinician poetry. Orestes' fall can be read as an implicit acknowledgement of the fickleness of human fortune and the limits of mortal achievement, a recurring epinician trope. ${ }^{60}$ Rather than simply undermining Attalus' success, the allusion sets it within the wider perspective of the mortal condition: like Orestes, Attalus is preeminent today, but there is no guarantee what tomorrow will bring. As in epinician poetry, this acknowledgement further augments Attalus' accomplishment - despite the vicissitudes of fortune, he has achieved a glorious Panhellenic victory. But it also situates him within the mortal sphere, marking his distance from the eternal bliss of the gods. Rather than undermining the poem's panegyric, therefore, this Sophoclean allusion fulfils a familiar aspect of epinician praise.

The Sophoclean episode is not the only significant intertext underlying our poem, however. These verses also contain an underappreciated Homeric texture that adds a further level to our interpretation. As previous scholars have noted, the occasional reuse of several epic idioms lends a general Homeric flavour to the epigram. ${ }^{61}$ But what is particularly striking is the precise Iliadic reference underlying the simile in verse 7: at the very hinge of the poem, Attalus' chariot team

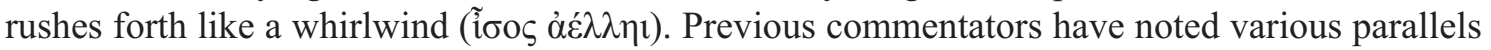
in epinician poetry and elsewhere for horses that 'run like the wind', ${ }^{62}$ but what has previously

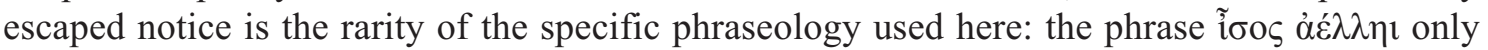
occurs twice before in extant literature, on both occasions to describe Hector's onslaught against the Greeks in consecutive books of the Iliad (Il. 11.295-98, 12.37-40):

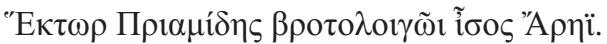

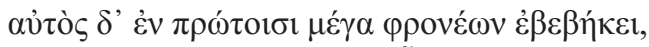

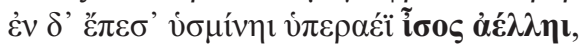

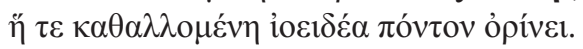

... Priam's son Hector, the peer of Ares, bane of mortals. He himself strode out among the foremost with high thoughts in his mind and fell on the conflict like a blustering whirlwind that swoops down and stirs the violet-hued sea.

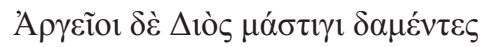

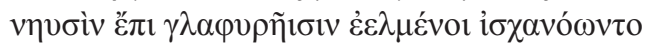

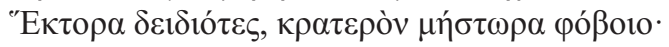

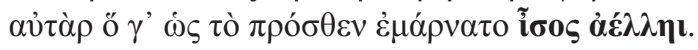

And the Argives, overpowered by the lash of Zeus, were penned in beside their hollow ships and held in check by their fear of Hector, the mighty deviser of rout. But he, as before, fought like a whirlwind.

The rarity of the phrase would naturally have invited ancient readers to draw a connection with these Homeric verses, especially since many would have been intimately familiar with the Iliad through schooling or study. ${ }^{63}$ The connection is signposted more strongly, moreover, by the poet's

60 Cf. Pind. Ol. 1.99-100, 1.114, 2.33-37; Pyth. 5.54; Nem. 6.6-7, 7.54-58; Isth. 4.5-6; Bacchyl. 5.5055; fr. 20b.23-24; fr. 25; fr. 54.

${ }^{61} \alpha$ $\tau \hat{\alpha} \rho$ ô $\tau$ oĩ $\sigma \mathrm{l}(v)$ (v. 9) is a common Homeric formula: cf. Il. 7.383, 23.29; Od. 1.9, etc. For $\dot{\alpha} \theta \rho o ́ \alpha . .$. $\pi \alpha ́ v \tau \alpha$, cf. Il. 22.271; Od. 1.43, etc.

${ }^{62}$ For example, Ebert (1972) 180; $c f$. n.41 above.
${ }^{63}$ As an aside, it is worth noting that the phrase $\dot{\omega} \varsigma$ $\tau$ ¿̀ $\pi \rho$ ó $\sigma \varepsilon \varepsilon v$ (Il. 12.40) seems to mark this Homeric repetition self-consciously: $c f$. T schol. Il. 12.40b: $\mu \varepsilon \dot{\varepsilon} \mu \eta \tau \alpha$ l

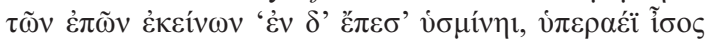
àź$\lambda \lambda \eta \imath$ '. The phrase is picked up occasionally by later Imperial epicists: Quint. Smyrn. 1.685; Nonnus Dion. 30.126; Orph. Arg. 840. 
retention of the epic Ionic dative $\alpha \dot{\varepsilon} \lambda \lambda \eta \iota$ amid a number of other Doric dialectal features: the simile is linguistically signposted as epic.

Through this echo, Attalus is presented as the foremost champion of his people, just as Hector was of the Trojans. We could, as with Orestes, ask how appropriate it is to compare Attalus to Hector - a man who was destined to die young and whose kingdom was soon to fall. But any 'further voice' seems even more distant here: the evoked episode comes from the very middle of the Iliad, the moment when the Trojans have the upper hand and are routing the Greeks in Achilles' absence. Just as Hector stands 'among the foremost' there (غ่v $\pi \rho \omega ́ \tau 01 \sigma 1, I l .11 .296)$, so too does

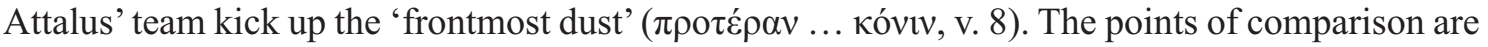
the shared pre-eminence and success of each hero, setting Attalus' agonistic victory alongside Hector's military triumph. ${ }^{64}$ On a more general level, Hector's role as a 'family man' also fits with Attalid familial values far more easily than any representative of the Tantalid household - indeed, this is another aspect of Pergamene ideology that may well have been developing at this very moment in response to Philetaerus' impending succession. ${ }^{65}$ At the heart of this parallel, however,

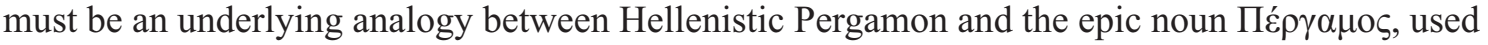
by Homer and later writers to denote the citadel of Troy. ${ }^{66}$ The Attalid kings exploited such a verbal parallel elsewhere: one of their mythical ancestors was the eponymous 'Pergamos', son of Andromache and Neoptolemus, whose very name and parentage established direct connections with the myth of the Trojan War. ${ }^{67}$ In a similar manner, by allusively recalling Hector in his prime in the Iliad, our poet not only co-opts the epic hero as an Attalid model of success and superiority, but similarly hints at a more direct connection back in time, drawing a link between the Attalids and the former rulers of Asia Minor in the heroic age.

Contrary to Fränkel's scepticism, therefore, this epigram proves to be a sophisticated and highly learned piece. Through its allusions to literary predecessors and careful exploitation of a Homeric verbal rarity, our poet exhibits a great deal of literary historical awareness. Yet this is not just a dry display of erudition. These allusions play a crucial encomiastic role, aligning Attalus with two major figures of heroic myth. Notably, both were princes of their respective kingdoms: Orestes as the son of Agamemnon in Mycenae and Hector as the son of Priam at Troy. Each thus provides a close parallel for Attalus, the adopted son of Philetaerus. With Pergamon's first transferral of dynastic power lingering on the horizon, such models would have resonated strongly against larger contemporary concerns over succession and dynastic continuity - especially given the explicit mention of Philetaerus near the end of the epigram. By associating the victor with both princes, moreover, our poet draws an implicit link between the ancient rulers of both mainland Greece and Asia Minor, reflecting the Attalids' own hybrid position as preservers of Greek culture in Anatolia. The allusions justify their current (and future) rule through the authorizing precedent of literary myth, while also asserting their success and superiority. ${ }^{68}$

64 This implied complementarity of war and games goes back to classical epinician itself: for example, Pyth. 1; Isth. 1.50. Cf. too Arcesilaus of Pitane's epigram, which celebrates Pergamon's fame for both 'arms' and

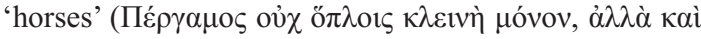

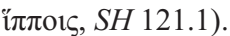

${ }^{65}$ Attalid familial values: see $\mathrm{n} .54$ above.

${ }^{66}$ Hom. Il. 4.508, 5.446, 5.460, 6.512, 7.21, 24.700; cf. Stesich. fr. 91a.3 Davies-Finglass; Ibycus S151.8, S224.7 PMGF; Pind. Ol. 8.42; Isth. 6.31; Pae. 6, fr. 52f.96; etc.

${ }^{67}$ Kosmetatou (2003) 168: 'The archaeological record suggests that at least one small heroon, dedicated to Pergamos Ktistes, was built in Pergamon, probably in the third century, and his head with the same legend occurs on some bronze coins of the Roman Imperial period.' Cf. Kosmetatou (1995); Gruen (2000) 23-24.

68 Alternatively, an anonymous reader suggests that the allusions to Orestes and Hector could be read more polemically, figuring Attalus' chariot victory as an act of revenge for Troy (the house of Priam) against the Greek victors of the past (the house of Agamemnon). However, I would still place the accent on Attalus' blending of the Orestes and Hector paradigms, reflecting the Attalids' own mixed heritage. 
This emphasis on pre-eminence may even be shared metapoetically by the poem itself. Athletic contests had long held a metaliterary resonance in the literary tradition, ${ }^{69}$ and by

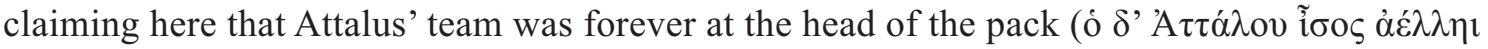

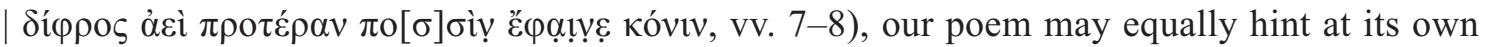
primacy amongst its predecessors; poet and victor stand at the head of the literary and political hierarchy. Similarly, the final image of $\dot{\alpha} o i ́ \delta \mu{ }^{\prime} \varsigma$ Fame travelling to Pergamon asserts the key role that poetry in general, and this poem in particular, will play in preserving and commemorating the Attalids' glory. ${ }^{70}$ Notably, the adjective $\alpha$ oí $\delta \mu o \zeta$ is another Homeric rarity, a hapax legomenon that derives from a well-known moment of Homeric self-reflexivity. In Iliad 6, Helen complains to Hector that Zeus has set an evil fate on her and Paris so that they might be the

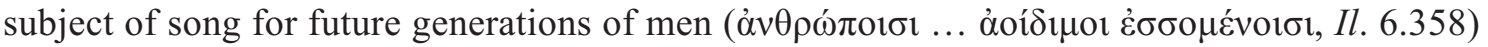
- a claim that acknowledges the role of the epic tradition (or even the Iliad itself) in preserving their story. ${ }^{71}$ In our epigram, the adjective qualifies $\varphi \eta \mu \alpha$, the agent that perpetuates fame, rather than the individuals whose stories will be kept alive; but the reuse of this Homeric rarity nevertheless suggests that Attalus and his achievement will be as fixed in the cultural consciousness as the Trojans of the epic past. By closing with this final image, the small epigram claims to match the memorializing power of Homeric epic, while once more establishing a close connection between Attalid Pergamon and the Homeric Trojans - a gesture of both literary and political pre-eminence.

It is worth concluding, however, by noting that there are numerous Ptolemaic parallels for all these allusive and political moves. We have already noted Theocritus' analogous use of a mythical exemplum in Idyll 18, to which we could also add Idyll 17, an encomium which associates Ptolemy Philadelphus with various epic models. ${ }^{72}$ But in the sphere of epinician poetry more specifically, we can compare both Posidippus' epigrammatic 'I $\pi \pi$ ik ́ (71-88 Austin-Bastianini) and Callimachus' generically hybrid epinicia, including those for the Ptolemaic courtier Sosibius (fr. 384 Pf.) and Queen Berenice (Aet. frr. 54-60j Harder). ${ }^{73}$ Many of Posidippus' poems display a similarly vivid 'reportage style' to our epigram; and many too focus on Ptolemaic victories, promoting the ideology and successes of the Alexandrian royal family just as our epigram celebrates the Attalid house. ${ }^{74}$ Among Callimachus' epinicia, meanwhile, the Victoria Berenices although part of a more extended narrative - shares a number of conceptual parallels with our epigram, highlighting the similar exploitation of epinician topoi by both Alexandrian and Pergamene poets. ${ }^{75}$ In sum, therefore, this epigram suggests that Pergamene poetics need not be radically different from those of Alexandria. Features that are often considered distinctively 'Alexandrian' can in fact be found in equal measure in Pergamon, a conclusion that should encourage us to reassess our narratives of literary history, especially those which posit an aesthetic dichotomy between the two locales.

69 On metapoetic charioteering, see Lovatt (2005) 23-32; Nelson (forthcoming b). The phenomenon, indebted to the metaphor of the 'chariot of song' (Nünlist (1998) 255-64), can be traced back as far as Parmenides (Forte and Smith (2016) 186-95, especially 195 n.29) and even Homer (Forte (2017) chapter 4).

${ }^{70} \mathrm{Cf}$. Arcesilaus of Pitane's epigram, which similarly ends by predicting that Pergamos 'will be much

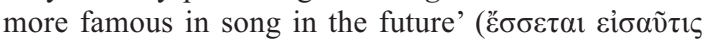

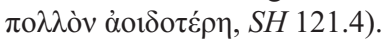

71 See de Jong (2006) 195-98. Simonides allusively reworks the adjective already in his Plataea Elegy of the early 470s BC (Lloyd-Jones (1994b) 1; Rawles (2018) 89, 98-99; Nelson (forthcoming c) section IV).

72 Hunter (2003) 60.

73 On Callimachus' epinicians, see Fuhrer (1992); (1993); Stephens (2019).

74 'Reportage style': van Bremen (2007) 366-67 on Posidippus 74 Austin-Bastianini. Ptolemaic resonances: Kosmetatou (2004); Fantuzzi (2005).

75 Victory of Berenice: ǒ $\sigma \theta \mu \alpha \tau 1$, fr. $54.9 \sim$

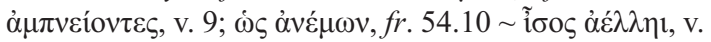

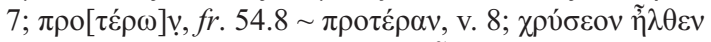

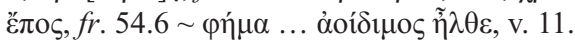




\section{III. 'Alexandrian' in all but name? Dionysodorus' satyr epigram}

This conclusion can be extended by exploring another inscribed poem found at Pergamon, a dedicatory epigram dated to the second decade of Attalus I's reign (230-220 BC), a number of decades after the inscribed epinician. ${ }^{76}$ As the text reveals, it too once accompanied a statue, in this case a bronze satyr dedicated to Attalus and the god Dionysus. The statue is now lost and the dedication's original location in Pergamon is unknown, ${ }^{77}$ but the text alone offers more than enough material to fuel further our reconsideration of Pergamene aesthetics (SGO I.06/02/05 = SEG 39.1334):

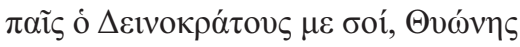

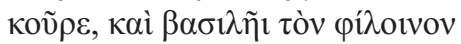

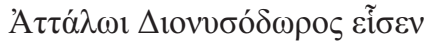

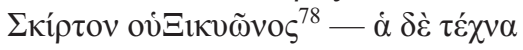

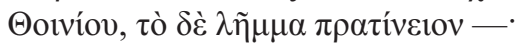

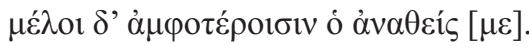

Dionysodorus from Sicyon, the son of Deinocrates, dedicated me, wine-loving Skirtos, to you, son of Thyone, and to King Attalus (the art is Thoinias', the conception Pratinaean). May he who dedicated me be dear to you both.

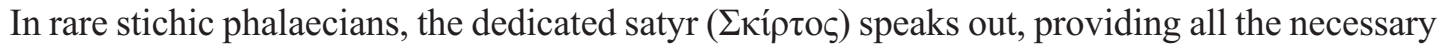
information about his origins for a passing reader. The dedicator, it turns out, was a prominent Pergamene courtier, the admiral Dionysodorus from Sicyon, who played a key role in the Battle of Chios against Philip V in $201 \mathrm{BC}$ and participated in the negotiations between Flamininus and Philip at Nicaea in 198 BC. $^{79}$ The sculptor was his fellow Sicyonian, Thoinias, a proponent of the school of Lysippus, ${ }^{80}$ whose work was exhibited throughout the Greek world. ${ }^{81}$ The composer of the poem is not named - perhaps Dionysodorus himself or his fellow Sicyonian Mnasalces $-{ }^{82}$ but whether composed by a local poet or not, the epigram is clearly designed to be read within a Pergamene context. The dedication's purpose fits into the usual do ut des formula of Greek religion: Skirtos hopes that Dionysodorus will be treated favourably by the king and god in future, a prayer whose positive fulfilment is perhaps reflected by the king's various benefactions to Dionysodorus' native city of Sicyon (Polyb. 18.16).

What is most striking about this poem, however, is its manifest erudition. At a basic level, this is visible in both metrics and language. The stichic use of a lyric metre, alongside the standardization of the caesura (after the seventh syllable), reflects the latest trends in Hellenistic versification, ${ }^{83}$ while the elaborately intertwined word order exhibits an artistic dexterity comparable to that found in one of Callimachus' dedicatory epigrams (Epigr. 39 Pf. $=$ Anth. Pal. 13.25). ${ }^{84}$ In addition, the

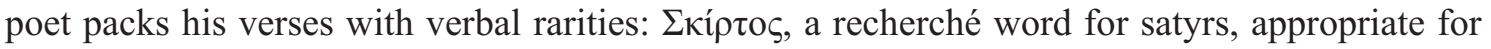

76 For this dating, see Müller (1989) 520.

77 Moreno (1994) 1.292-96 suggests that the marble 'dancing satyr' found in the Antikythera wreckage might be a replica of the original Pergamene statue, given the fit with the incisions on the statue base (though Müller (1989) 534 is wary of any attempt at such reconstruction).

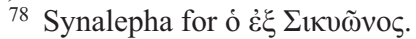

${ }^{79}$ Polyb. 16.2-9, 18.2.2; Livy 32.33.5 (Müller (1989) 508-15). For this interplay of politics, poetry and patronage, compare the Ptolemaic admiral Callicrates of Samos (see especially Bing (2003)).

${ }^{80}$ His father Teisicrates had been the pupil of
Lysippus' son Euthycrates (Plin. HN 34.67; Müller (1989) 518-19).

${ }^{81}$ Delos (IG XI.4.1088), Oropus (IG VII.384, 431), Tanagra (IG VII.521) and his native city (IG IV.427, 428) (Müller (1989) 516).

82 Dionysodorus: Müller (1989) 535. Mnasalces: Lehnus (1996).

${ }^{83}$ See Kassel (1990), who notes how the caesura in verse 3 neatly divides Dionysodorus' compound name in

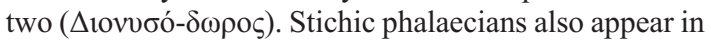
Anth. Pal. 9.598 (Theoc. Epigr. 22), 13.6 (anon.).

${ }^{84}$ I thank an anonymous reviewer for drawing my attention to this Callimachean parallel. 


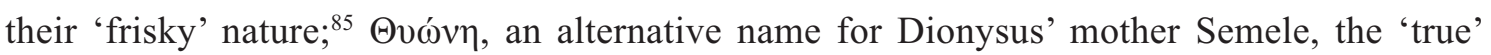

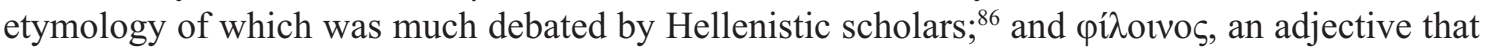
occurs only once before in extant poetry, as part of Zethus' criticism of Amphion's musical life in Euripides' Antiope ( $f r .183 \mathrm{Tr} G F$ ): the Satyr's reuse of the word here reclaims it as a positive attribute for his own drunken, Dionysiac state. ${ }^{87}$

Besides such minutiae, however, the poem also exhibits a larger interest in literary history. The penultimate line, in claiming that 'the conception is Pratinaean', fashions this satyr in a specifically literary mould, as a prototypical representative of satyr play, a genre whose invention was attributed to Pratinas of Phlius. ${ }^{88}$ Such a reference would have carried a significant local resonance for Dionysodorus, given that Phlian territory neighboured that of his hometown Sicyon. But it also betrays a learned interest in the origins and categorization of poetic genres. This literary aetiology is further marked both linguistically and dialectally: the Doric inflection of $\dot{\alpha} \delta \dot{\varepsilon} \tau \dot{\varepsilon} \chi v \alpha$ in verse 4 flags not just Dionysodorus' and Thoinias' Sicyonian heritage, but also the satyr's own (literary) Phlian ancestry, ${ }^{89}$ while the use of $\lambda \tilde{\eta} \mu \mu \alpha$ in verse 5 has a self-consciously scholarly resonance: when used in a literary context, the noun usually means 'subject matter' or 'theme', ${ }^{90}$ but here it could rather be taken, as Peter Bing notes, "in its scholarly sense of "lemma," a heading or rubric of a comment in the scholia': in any literary catalogue, this satyr belongs under a 'Pratinaean' heading. ${ }^{91}$ Our epigram thus not only flaunts its literary-historical expertise, but does so through a specifically scholarly framework.

All of this, it is worth noting, is very similar to a pair of epigrams by Dioscorides on satyrs atop dramatists' tombs (Anth. Pal. 7.37, 7.707 = 22-23 Gow-Page, HE 1597-1616), both of which also emphasize the creatures' literary pedigree. In the poem on Sophocles, the satyr comes explic-

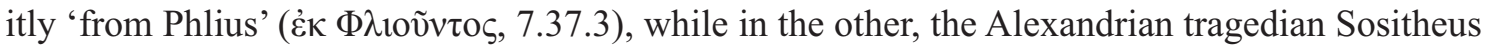

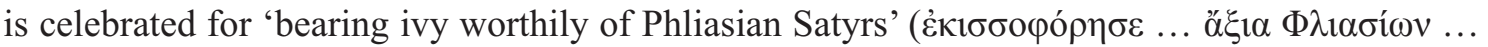
$\Sigma \alpha \tau \dot{\rho} \omega \omega v, 7.707 .3-4)$ and causing Skirtos to remember his fatherland ( $\pi \alpha \tau \rho i ́ \delta ', 7.707 .6)$ with his

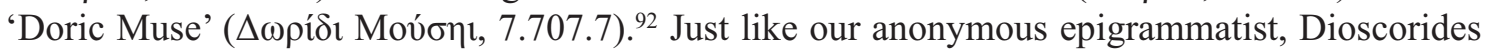
alludes obliquely to the literary origins of satyr play through geographical references to Pratinas' homeland. Given that Dioscorides was closely connected with Ptolemaic Egypt, ${ }^{93}$ this complementarity highlights once more the continuities of literary interest between Pergamon and Alexandria. Audiences in both locales were expected to detect the learned reference. It is difficult to see an underlying aesthetic contrast here.

This conclusion is strengthened further when we note a possible Callimachean echo in verses 4-

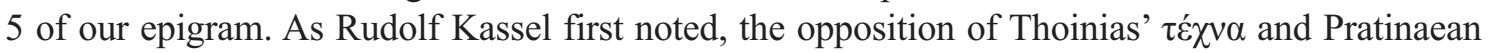
$\lambda \tilde{\eta} \mu \mu \alpha$ is very similar to the opening of Callimachus' sixth Iambus, which treats another divine statue,

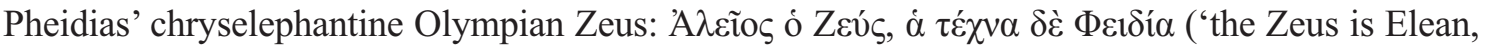
the art is Pheidias", fr. 196.1 Pf.). ${ }^{94}$ Some have seen here a direct allusion to Callimachus; indeed, Wolfgang Luppe suggests that the epigram's sole Doricism ( $\dot{\alpha} \delta \dot{\varepsilon} \tau \varepsilon \dot{\varepsilon} \chi v \alpha, v .4)$ could be a 'bow to the

\footnotetext{
85 Cornutus (De natura deorum 30) derives the name

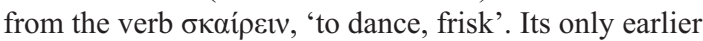
poetic occurrence is in an epigram by Dioscorides (Anth. Pal. 7.707.3), cf. below. For an analysis of the noun's attestations, see Dettori (2014).

${ }^{86}$ Schol. Ap. Rhod. Argon. 1.636; schol. Pind. Pyth. 3.177a. The word seems closely connected with Semele's apotheosized form after Dionysus had recovered her from the Underworld (Apollod. Bibl. 3.5.3; Diod. Sic. 4.25.4), so it was perhaps of some relevance to the Pergamene royal cult of Dionysus Kathegemon.

87 The epigram's extreme hyperbaton even seems to mimic this drunkenness, chaotically interweaving dedi-
}

cator, dedicatees and dedication (Kerkhecker (1991) 31)

88 On Pratinas, see Snell (1986) 79-84 (TrGF I 4); Müller (1989) 521-27; Wright (2016) 14-17.

${ }^{89}$ Cf. Kerkhecker (1991) 31; Bing (2009) 155. On the allusive significance of dialect in inscribed epigram, see section II above with n. 30

${ }^{90}$ LSJ s.v. $\lambda \tilde{\eta} \mu \mu \alpha$ III; Müller (1989) 522. $C f$.

[Longinus], Subl. 10.1, 15.10.

91 Bing (2009) 155 n.16.

92 Cf. Müller (1989) 527-39.

93 See Gow and Page (1965) 2.235; Fraser (1972) $1.603-04$.

94 Kassel (1990) 299. 
master, and his Doric poem' ${ }^{95}$ But we should be cautious of positing such a direct reference. As we have seen already, the Doricism can be amply explained as a geographical nod to Sicyon and Phlius, especially since it follows immediately after the emphatically delayed mention of Dionysodorus'

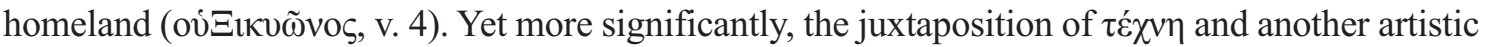
element appears to have been a stock motif of artistic signatures: the epigram affixed to the Capitoline Tabula Iliaca similarly distinguishes the $\tau \dot{\varepsilon} \chi \vee \eta$ of Theodorus and the $\tau \alpha \dot{\xi} \xi 1 \varsigma$ of Homer, ${ }^{96}$ while an epigram for a skyphos depicting the sack of Troy opposes the $\gamma \rho \alpha ́ \mu \mu \alpha$ of Parrhasius and the $\tau \dot{\varepsilon} \chi v \alpha$ of Mys. ${ }^{97}$ It is likely that all these examples offer variations on a common artistic topos, of which Callimachus' is the most radical; whereas our epigrammatic examples set $\tau \dot{\varepsilon} \chi \nu \eta$ against some other general quality of composition $(\lambda \tilde{\eta} \mu \mu \alpha, \tau \alpha \dot{\xi} \xi 1 \zeta, \gamma \rho \alpha \dot{\mu} \mu \alpha)$, Callimachus' epigrammatically infused iambus sets it against the figure of Zeus himself. ${ }^{98}$ Of course, we cannot rule out entirely the possibility of direct influence, but given this broader motif, I would suggest that the parallel between Callimachus' poem and our epigram is better understood as a reflection of the two poets' parallel engagements with epigrammatic tradition..$^{99}$ On any interpretation, however, this linguistic similarity further demonstrates the complementarity of Alexandrian and Pergamene poetics.

Even from this brief analysis, therefore, it is no surprise that Peter Parsons once remarked that 'it would be difficult to find a more "Alexandrian" epigram than this'. ${ }^{100}$ Our poem is a polished and erudite composition that not only revels knowingly in its learning, but also shares a number of similarities with the work of two Alexandrian poets, Dioscorides and Callimachus - similarities that are not just superficial, but rather extend across style, substance and subject matter. It is thus impossible to maintain a neat division between the poetics of Pergamon and Alexandria. This epigram, explicitly addressed to the Pergamene king, is the clearest testimony to the refinement that Pergamene poetry could attain, a masterpiece of verbal, technical and scholarly control, and its connection with a prominent Pergamene courtier attests to the Attalids' strong desire to patronize and be associated with such intricate work. There seems little here that could be called 'baroque', or even 'un-' or 'anti-Alexandrian'.

\section{Pergamene aesthetics reconsidered}

From this examination, what stands out is not the difference, but rather the similarity between our two epigrams and the poetic output of third-century Alexandria. Pergamene poets could be just as allusive and scholarly as their Ptolemaic peers and were similarly engaged in elaborate praise of their rulers' ancestry, beneficence and athletic success - a conclusion whose contours would stay unchanged if we explored further extant epigrams and fragments of a Pergamene provenance. ${ }^{101}$ Of course, given the extremely fragmentary state of this Pergamene poetry, we should be wary of drawing too sweeping conclusions, especially since our analysis rests on a limited sample of

\footnotetext{
${ }^{95}$ Luppe apud Kerkhecker (1999) 149 n.11. Literary incipits are a common target of allusion: $c f$. lyric echoes of Il. 1.1 ( Alc. fr. 44.8 Voigt; Bacchyl. 13.110-12) and Horace's famous 'motto' technique ( $c f$. Nelson (2019) n.94 with further bibliography).

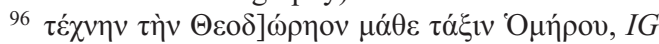
XIV.1284.

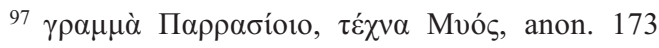
Page, FGE 1852-53 (Ath. Deipn. 11.782b). See Squire (2011) 83-85 for this epigram's play with scale.

${ }^{8}$ For such 'art of variation' in Hellenistic epigram, see Tarán (1979).

${ }^{9} C f$. Kerkhecker (1991) 29, who also suspects a parallel of thought and topic, rather than an intentional citation.
}

100 Parsons (1993) 14: 'Difficilmente si può trovare un epigramma più “alessandrino".' $C f$. Müller (1989) 537: 'die philologische Wissenschaft in Pergamon ... weder in Inhalt noch in Niveau hinter der alexandrinischen Konkurrenz zurückblieb'.

101 For example, $I G$ XI.4.1105, an epigram for Philetaerus on Delos (see Bing and Bruss (2007) 8-11; Kosmetatou (forthcoming)); Nicander's Hymn to Attalus, fr. 104 Gow-Scholfield (see Nelson (2020)); the anonymous Anth. Plan. 91, which describes a relief of Heracles' labours on the Pergamene acropolis (see Robert (1984)); Herodicus' epigram against the Aristarcheans $($ SH $494=1$ Page, FGE 233-38 = fr. 1 Broggiato (2014)); and Herodicus' hexametric fragment, which features Aspasia offering Socrates advice about his love for Alcibiades, manipulating epic, lyric and Platonic precedent $($ SH $495=f r .12$ Broggiato (2014)). 
evidence - a sample, moreover, that is dominated by a single literary genre (epigram) that has a natural inclination towards the refined and the small-scale. As it stands, it is thus unclear how unified and coherent a poetic 'school' we should imagine to have existed in Pergamon, or how works of other genres that are now completely lost would fit into the picture, such as Musaeus' encomia of Eumenes and Attalus ( $\mathrm{SH}$ 561) or his Perseis, an allegedly ten-book epic (SH 560). Yet even so, as Apollonius' Argonautica has shown, a multi-book epic is not necessarily incompatible with so-called 'Callimachean' tastes. ${ }^{102}$ Our evidence is undeniably limited, but from what survives there is nevertheless no good reason to continue subscribing to the idea of a deep-rooted opposition between Alexandrian refinement and the Pergamene baroque. When we compare like with like, it is the literary and aesthetic similarities that shine through.

Even when we turn back to Pergamene and Alexandrian art, moreover, the contrast between the baroque and refined styles simply does not hold. As Andrew Stewart has noted, Alexandria too exhibited 'recognizably baroque architecture' by at least the second century BC, paralleling the grandeur of Pergamon's public displays. ${ }^{103}$ And much Pergamene art, too, is heavily allusive in a manner that many would call 'Alexandrian'. The Great Altar's Gigantomachy, in particular, that most 'baroque' of monuments, alludes to a wide range of earlier art, history and literature. In Stewart's words, it is 'a kind of thesaurus of masterpieces of Greek art'. ${ }^{104}$ Nor was all Pergamene art even as grandiose and baroque as the Gigantomachy; John Onians has suggested that the Altar's interior Telephus frieze corresponds in some ways to 'Callimachean' tastes in its smaller scale and episodic structure. ${ }^{105}$ But even more tellingly, we could look to Pergamene palace mosaics, smallscale compositions that engaged playfully with the nature and limits of their artistic medium - a closer parallel for the self-conscious experimentation of Alexandrian poets. Particularly notable is the work of Sosus. His 'unswept room' mosaic imitated a floor cluttered with the debris of a feast, a virtuosic display of trompe l'oeil, while his dove mosaic seems to have alluded to a scholarly controversy over Nestor's cup: a striking specimen of both minute composition and scholarly spectacle. ${ }^{106}$ Rather than distinguish between Pergamene and Alexandrian artistic styles, it would thus be better to draw a parallel contrast in each kingdom between the more refined display of palatial interiors and the bombastic baroque of public art. ${ }^{107}$ The differences between these Hellenistic art forms derive not from an underlying aesthetic divide between two kingdoms, but rather from differing contexts of display. In art, as in literature, we cannot infer a neat geographical opposition between Pergamon and Alexandria.

Ultimately, the issue thus draws back to Jim Porter's important discussion of Hellenistic aesthetics. As he has demonstrated, what underpins Hellenistic poetry is not so much simply an obsession with the small-scale and the refined, as with the deliberate contrast of different scales and extremes. In his words, 'The exponents of Hellenistic culture had an urge for leptotess, but they also knew the opposite urge: an urge for grandeur, for the spectacular, for cosmic aspiration; ... for the peculiar, the monstrous and the baroque ...' ${ }^{108}$ After all, even the most refined of 'Alexandrian' poetry contains moments of a grander and more baroque character; scholars have previously

102 See, for example, DeForest (1994). The aesthetic opposition posited between Pergamon and Alexandria is in many ways reminiscent of that once imagined between Apollonius as the grandiose epicist and Callimachus as the refined, small-scale writer (cf. Cameron (1995) 26364 with further references). In both cases, the stark dichotomy cannot be maintained under scrutiny.

103 Stewart (2014) 35. On the theatricality of public display more generally in the Hellenistic world, see Chaniotis (1997).

104 Stewart (1993) 165, see also 153-69 on historical and sculptural allusions in the Gigantomachy.
105 Onians (1979) 144-46.

$106 C f$. Plin. HN 36.184; Parlasca (1963). See too the signature of Hephaestion depicted on a mosaic in Palace $\mathrm{V}$ at Pergamon: one corner of the parchment has broken free from its wax and curls up, playfully contrasting the fragile parchment with the durable tesserae through which it is fixed (Dunbabin (1999) 28-30).

107 On surviving Alexandrian and Pergamene mosaics, see Dunbabin (1999) 22-26 and 26-30, respectively.

108 Porter (2011) 295. 
pinpointed Heracles' fight against the Giants in the Argonautica (Argon. 1.989-95) and both Apollonius' and Theocritus' descriptions of the burly Amycus (Argon. 2.1-97; Id. 22.44-52) as instances of a more baroque mode. ${ }^{109}$ And even our epinician epigram may display baroque elements in its anaphoric $\pi \mathrm{o} \lambda \lambda \dot{\alpha}$ (vv. 1-2), crowded chariots ( $\left.\dot{\alpha} \theta \rho \alpha_{\alpha} \alpha, \mathrm{vv} .3-4\right)$ and myriads of Greeks ( $\mu$ vió $\sigma \mathrm{v} v, \mathrm{v}$. 10), which together create a vivid sense of scale and bustle. ${ }^{110}$ We thus cannot distinguish Pergamene and Alexandrian aesthetics as an opposition between the baroque and the refined. Instead, we should acknowledge that the poetry and art of both kingdoms could exploit both these extremes.

But this conclusion still leaves unanswered the question of what we should make of these similarities. How should we account for them, and what do they tell us about the larger aesthetic map of the Hellenistic world? One natural option is to follow Peter Parsons in seeing them as the result of direct influence from Alexandria. ${ }^{11}$ The late development of the Pergamene monarchy would have left it open to influence from other kingdoms abroad. Just as the Attalids appear to have been inspired by the Alexandrian library, so too could their poets have been influenced by their famous Ptolemaic predecessors.

However, we should be cautious of such a simple and linear narrative of influence. In the case of Dionysodorus' epigram, we have already concluded that direct debt to Callimachus is not the likeliest explanation for their similar language, while the early date of the epinician epigram (during Philetaerus' reign) means that it could very well be a contemporary or even predecessor of much Ptolemaic poetry, not simply an imitative successor. ${ }^{112}$ More generally, it is also too reductive to focus solely on Alexandria and Pergamon as sites of interaction, without taking account of possible influences from numerous other Hellenistic centres. We have already seen that Dionysodorus and Thoinias came from Sicyon, and we know that the Attalids employed a whole host of sculptors of different nationalities in the construction of the Great Altar. ${ }^{113}$ There is every reason to suspect that they would have patronized a similarly diverse range of poets, encouraging the cross-fertilization of multiple literary traditions. Moreover, given Alexandria's own likely debt to other earlier literary cultures, we should be wary of regarding it as the fons et origo of a specific aesthetic style anyway. ${ }^{114}$

While we cannot rule out some stimulus from Ptolemaic Egypt, therefore, it would nevertheless be too simplistic to frame all these similarities as a case of direct, unmediated influence. Instead, we should acknowledge that both Alexandria and Pergamon were part of a larger, elite poetic koine that stretched far and wide across the Hellenistic world, fostered by the constant migration of itinerant artists and poets. ${ }^{115}$ This is, of course, not to argue for monochrome unity across the Hellenistic world; local variation would have existed across space and time. In this paper, for example, we have noted the Attalids' particularly strong concern with familial unity, as well as

109 Fowler (1989) 32-43, 88-91; Zanker (2015) 53. Other suggested examples include the storm at Id.22.822, the Nemean lion of $I d .25$ and the Callimachean Cyclopes (Hymn 3.51-61).

110 On enargeia ('vividness') as a hallmark of the baroque, see Stewart (2006) 128; Schultz (2011) 318.

111 Parsons (1993) 14.

112 For the date of the epigram, see section II above with n.24. It certainly pre-dates Callimachus' Victory of Berenice (for the date of which, see Harder (2012) 2.390 ), so if the verbal parallels in $n .75$ above are not simply the result of generic topoi, could Callimachus even be alluding to the Attalid epigram?

113 Thimme (1946) conjectures about 40 sculptors in total. Thanks to the inscribed signatures on the Gigantomachy ( $I v P$ I.70-85), we know the ethnicities of at least some: besides Pergamenes $(72,75,84)$, there was also an Athenian (74), two men from Tralleis (76) and probably
Rhodians too (70, 71) (see Hansen (1971) 334-36).

114 For example, Rhodes appears to have been a significant locus for proto-Callimachean poetics (through Simias, Timachidas, etc.), as does Cos (especially through Philitas, tutor of Ptolemy II; $c f$. too the prominence of Cos in Theocritus' pastoral Idylls (Lawall (1967)), which has prompted biographical speculation since antiquity that the poet once resided on the island:

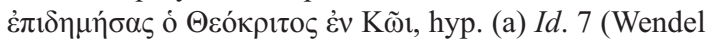
(1914) 76).

115 As an example of these international interconnections, note that the Sicyonian Thoinias, the sculptor of Dionysodorus' Pergamene dedication, also produced a statue at Oropus on mainland Greece of a certain Heraclitus of Halicarnassus ( $I G$ VII.431), very possibly the elegiac poet famously lamented by Callimachus in Alexandria (Epigr. 2 Pf. = Anth. Pal. 7.80); see Müller (1989) 516-17. 
their intertextual association with both Greek and Asian models in the forms of Orestes and Hector. But, ultimately, we must conclude that Alexandrian and Pergamene poets were both participants and partners in a far bigger, international poetic system. If a sense of aesthetic opposition between the two continues to linger, this is simply because of the different ratios of what has survived from each. In reality, scholarly narratives of a gigantomachic clash between the Pergamene baroque and Alexandrian refinement, however appealing to our structuralist urges, are as fictional and fabricated as the swathes of gigantomachic epic reconstructed from the Great Altar itself.

\section{Bibliography}

Abbreviations

$I v P=$ Fränkel, M. (1890-1895) Die Inschriften von Pergamon (2 vols) (Berlin)

$S G O=$ Merkelbach, R. and Stauber, J. (1998-2004) Steinepigramme aus dem griechischen Osten (5 vols)

(Stuttgart, Munich and Leipzig)

SH = Lloyd-Jones, H. and Parsons, P.J. (1983) Supplementum Hellenisticum (2 vols) (Berlin)

Acosta-Hughes, B. (2015) 'À l'image d'Hélène ou comment se figurer une reine: sur quelques représentations d'Arsinoé II', in M. Cojannot-Le Blanc, C. Pouzadoux and É. Prioux (eds), L'Hérö̈que et le Champêtre 2: appropriation et déconstruction des théories stylistiques dans la pratique des artistes et dans les modalités d'exposition des oeuvres (Nanterre) 41-58

Acosta-Hughes, B. and Stephens, S. (2012) Callimachus in Context: From Plato to the Augustan Poets (Cambridge)

Alden, M.J. (2017) Para-Narratives in the Odyssey: Stories in the Frame (Oxford)

Allen, R.E. (1983) The Attalid Kingdom: A Constitutional History (Oxford)

Austin, C. and Bastianini, G. (2002) Posidippi Pellaei quae supersunt omnia (Milan)

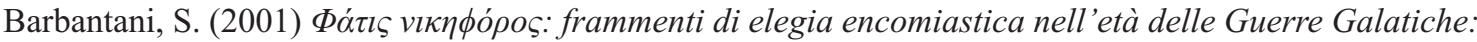
Supplementum Hellenisticum 958 e 969 (Milan)

- (2012) 'Hellenistic epinician', in P. Agócs, C. Carey and R.J. Rawles (eds), Receiving the Komos: Ancient and Modern Receptions of the Victory Ode (BICS Supplement 112) (London) 37-55

- (2014) "“Attica in Syria": Persian war reenactments and reassessments of the Greek-Asian relationship: a literary point of view', Erga-Logoi 2, 21-91

Bing, P. (1988) The Well-Read Muse: Present and Past in Callimachus and the Hellenistic Poets (Hypomnemata 90) (Göttingen)

- (2003) 'Posidippus and the admiral: Kallikrates of Samos in the Milan epigrams', GRBS 43, 243-66

- (2009) 'Allusion from the broad, well-trodden street: the Odyssey in inscribed and literary epigram', in P. Bing, The Scroll and the Marble: Studies in Reading and Reception in Hellenistic Poetry (Ann Arbor) $147-74$

Bing, P. and Bruss, J.S. (2007) 'Introduction', in P. Bing and J.S. Bruss (eds), Brill's Companion to Hellenistic Epigram (Leiden and Boston) 1-26

Blank, D. (2005) 'Varro's anti-analogist', in D. Frede and B. Inwood (eds), Language and Learning: Philosophy of Language in the Hellenistic Age (Cambridge) 210-38

Broggiato, M. (2001) Cratete di Mallo: i frammenti (Pleiadi: studi sulla letteratura antica 2) (La Spezia)

- (2005) 'I frammenti del grammatico Zenodoto di Mallo', SemRom 8, 135-52

- (2014) Filologia e interpretazione a Pergamo: la scuola di Cratete (Studi umanistici - Antichistica, Collana Studi e Ricerche 13) (Rome)

Brückner, A. (1904) 'Wann ist der Altar von Pergamon errichtet worden?', AA 218-24

Brumbaugh, M. (2016) 'Kallimachos and the Seleukid Apollo', TAPhA 146, 61-97

Bubeník, V. (1989) Hellenistic and Roman Greece as a Sociolinguistic Area (Amsterdam and Philadelphia)

Buxton, R.G.A. (1994) Imaginary Greece: The Contexts of Mythology (Cambridge)

Cameron, A. (1995) Callimachus and his Critics (Princeton)

Chaniotis, A. (1997) 'Theatricality beyond the theater: staging public life in the Hellenistic world', in B. Le Guen (ed.), De la scène aux gradins: thêatre et représentations dramatiques après Alexandre le Grand (Pallas 47) (Toulouse) 219-59 
Chrubasik, B. (2013) 'The Attalids and the Seleukid kings, 281-175 BC', in P. Thonemann (ed.), Attalid Asia Minor: Money, International Relations, and the State (Oxford) 83-119

Coleman, K.M. (2019) 'Epigram, society, and political power', in C. Henriksén (ed.), A Companion to Ancient Epigram (Hoboken) 59-75

Coqueugniot, G. (2013) 'Where was the royal library of Pergamum? An institution found and lost again', in J. König, K. Oikonomopoulou and G. Woolf (eds), Ancient Libraries (Cambridge) 109-23

Coughlan, T.S. (2016) The Aesthetics of Dialect in Hellenistic Epigram (Ph.D. Diss. Cincinnati)

Davies, M. and Finglass, P. (2014) Stesichorus: The Poems (Cambridge Classical Texts and Commentaries 54) (Cambridge)

de Jong, I.J.F. (2006) 'The Homeric narrator and his own kleos', Mnemosyne 59, 188-207

DeForest, M.M. (1994) Apollonius'Argonautica: A Callimachean Epic (Mnemosyne Supplement 142) (Leiden)

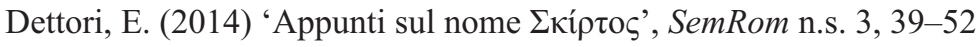

Dunbabin, K.M.D. (1999) Mosaics of the Greek and Roman World (Cambridge)

Düring, I. (1941) Herodicus the Cratetean: A Study in Anti-Platonic Tradition (Kungl. Vitterhets historie och antikvitets akademiens handlingar 51.2) (Stockholm)

Ebert, J. (1972) Griechische Epigramme auf Sieger an Gymnischen und Hippischen Agonen (Abhandlungen der Sächsischen Akademie der Wissenschaften zu Leipzig, Philologisch-historische Klasse 63.2) (Berlin)

Edson, C.F. Jr (1934) 'The Antigonids, Heracles, and Beroea', HSPh 45, 213-46

Fantuzzi, M. (1988) 'L'epos ellenistico “tradizionale” prima e dopo Ziegler', in K. Ziegler, L'epos ellenistico: un capitolo dimenticato della poesia greca (Bari) xxv-liii

- (2005) 'Posidippus at court: the contribution of the 'I $\pi$ - เќ of P. Mil. Vogl. VIII 309 to the ideology of Ptolemaic kingship', in K.J. Gutzwiller (ed.), The New Posidippus: A Hellenistic Poetry Book (Oxford) $249-68$

Fantuzzi, M. and Hunter, R.L. (2004) Tradition and Innovation in Hellenistic Poetry (Cambridge)

Finglass, P.J. (2007) Sophocles: Electra (Cambridge Classical Texts and Commentaries 44) (Cambridge)

Forte, A.S.W. (2017) Tracing Homeric Metaphor (Ph.D. Diss. Harvard)

Forte, A.S.W. and Smith, C.C. (2016) 'New riders, old chariots: poetics and comparative philosophy', in R. Seaford (ed.), Universe and Inner Self in Early Indian and Early Greek Though (Edinburgh) 186-203

Fowler, B.H. (1989) The Hellenistic Aesthetic (Madison)

Fränkel, M. (1890) Die Inschriften von Pergamon 1: Bis zum Ende der Königszeit (Berlin)

Fraser, P.M. (1972) Ptolemaic Alexandria (3 vols) (Oxford)

Fuhrer, T. (1992) Die Auseinandersetzung mit den Chorlyrikern in den Epinikien des Kallimachos (Schweizerische Beiträge zur Altertumswissenschaft 23) (Basel)

- (1993) 'Callimachus' epinician poems', in M.A. Harder, R.F. Regtuit and G.C. Wakker (eds), Callimachus (Hellenistica Groningana 1) (Groningen) 79-97

Gallotta, S. (2016) 'Argos in the third century BC', paper presented at 'The Hellenistic Peloponnese: New Perspectives', Leicester, 6 May 2016

Gow, A.S.F. and Page, D.L. (1965) The Greek Anthology: Hellenistic Epigrams (2 vols) (Cambridge)

Gow, A.S.F. and Scholfield, A.F. (1953) Nicander: The Poems and Poetical Fragments (Cambridge)

Graninger, D. (2011) Cult and Koinon in Hellenistic Thessaly (Brill Studies in Greek and Roman Epigraphy 1) (Leiden and Boston)

Gruen, E.S. (2000) 'Culture as policy: the Attalids of Pergamon', in N.T. de Grummond and B.S. Ridgway (eds), From Pergamon to Sperlonga: Sculpture and Context (Hellenistic Culture and Society 34) (Berkeley, Los Angeles and London) 17-31

Gutzwiller, K.J. (2007) A Guide to Hellenistic Literature (Malden and Oxford)

Hadjimichael, T.A. (2015) 'Sports-writing: Bacchylides' athletic descriptions', Mnemosyne 68, 363-92

- (2019) The Emergence of the Lyric Canon (Oxford)

Hansen, E.V. (1971) The Attalids of Pergamon (Cornell Studies in Classical Philology 36) (2nd edition) (Ithaca NY and London)

Harder, M.A. (2012) Callimachus, Aetia: Introduction, Text, Translation and Commentary (2 vols) (Oxford)

Hardie, P.R. (1986) Virgil's Aeneid: Cosmos and Imperium (Oxford)

Hornblower, S. (2004) Thucydides and Pindar: Historical Narrative and the World of Epinikian Poetry (Oxford)

- (2015) Lykophron: Alexandra: Greek Text, Translation, Commentary, and Introduction (Oxford) 
- (2018) Lykophron's Alexandra, Rome, and the Hellenistic World (Oxford)

Hunter, R.L. (1996) Theocritus and the Archaeology of Greek Poetry (Cambridge)

- (2003) Theocritus: Encomium of Ptolemy Philadelphus (Hellenistic Culture and Society 39) (Berkeley, Los Angeles and London)

Hutchinson, G.O. (2016) 'Pentameters', in E. Sistakou and A. Rengakos (eds), Dialect, Diction, and Style in Greek Literary and Inscribed Epigram (Trends in Classics Supplement 43) (Berlin and Boston) 119-37

Jacques, J.-M. (2006) 'Nicandre de Colophon, poète et médecin', in C. Cusset (ed.), Musa docta: recherches sur la poésie scientifique dans l'antiquité (Saint-Étienne) 19-48

Johnson, R.R. (1970) 'Ancient and medieval accounts of the "invention" of parchment', California Studies in Classical Antiquity 3, 115-22

Kähler, H. (1948) Der grosse Fries von Pergamon: Untersuchungen zur Kunstgeschichte und Geschichte Pergamons (Berlin)

Kassel, R. (1990) 'Die Phalaeceen des neuen hellenistischen Weihepigramms aus Pergamon', ZPE 84, 299 300

Katz, M.A. (1991) Penelope's Renown: Meaning and Indeterminacy in the Odyssey (Princeton)

Kerkhecker, A. (1991) 'Zum neuen hellenistischen Weihepigramm aus Pergamon', ZPE 86, 27-34

- (1999) Callimachus' Book of Iambi (Oxford)

Kosmetatou, E. (1995) 'The legend of the hero Pergamus', AncSoc 26, 133-44

- (2000) 'Lycophron's Alexandra reconsidered: the Attalid connection', Hermes 128, 32-53

- (2003) 'The Attalids of Pergamon', in A. Erskine (ed.), A Companion to the Hellenistic World (Oxford) $159-74$

- (2004) 'Constructing legitimacy: the Ptolemaic Familiengruppe as a means of self-definition in Posidippus' Hippika', in B. Acosta-Hughes, E. Kosmetatou and M. Baumbach (eds), Labored in Papyrus Leaves: Perspectives on an Epigram Collection Attributed to Posidippus (P. Mil. Vogl. VIII 309) (Cambridge MA and London) 225-46

- (forthcoming) 'The eunuch Philetairos: Pergamene founding father and Galatian-slayer', in A. Coşkun (ed.), Galatian Victories and Other Studies into the Agency and Identity of the Galatians in the Hellenistic and Early-Roman Periods (Colloquia Antiqua 33) (Leuven)

Kosmin, P.J. (2014) The Land of the Elephant Kings: Space, Territory, and Ideology in the Seleucid Empire (Cambridge MA and London)

- (2018) Time and its Adversaries in the Seleucid Empire (Cambridge MA and London)

Lawall, G. (1967) Theocritus' Coan Pastorals: A Poetry Book (Washington DC)

Lefkowitz, M.R. (1984) 'The poet as athlete', Journal of Sport History 11, 18-24

Lehnus, L. (1996) 'On the metrical inscription found at Pergamum (SEG 39.1334)', CQ 46, 295-97

Linant de Bellefonds, P. and Prioux, É. (2018) Voir les mythes: poésie hellénistique et arts figurés (Antiqua 18) (Paris)

Lloyd-Jones, H. (1994a) Sophocles: Ajax, Electra, Oedipus Tyrannus (Loeb Classical Library 20) (Cambridge MA and London)

- (1994b) 'Notes on the New Simonides', ZPE 101, 1-3

Looijenga, A.R. (2014) 'The spear and the ideology of kingship in Hellenistic poetry', in M.A. Harder, R.F. Regtuit and G.C. Wakker (eds), Hellenistic Poetry in Context (Hellenistica Groningana 20) (Leuven, Paris and Walpole) 217-45

Lovatt, H. (2005) Statius and Epic Games: Sport, Politics and Poetics in the Thebaid (Cambridge)

Lyne, R.O.A.M. (1987) Further Voices in Vergil's Aeneid (Oxford)

Magnelli, E. (2010) 'Nicander', in J.J. Clauss and M. Cuypers (eds), A Companion to Hellenistic Literature (Oxford) 211-23

Marks, J. (2008) Zeus in the Odyssey (Hellenic Studies 31) (Washington DC)

Massimilla, G. (2000) ‘Nuovi elementi per la cronologia di Nicandro', in R. Pretagostini (ed.), La letteratura ellenistica: problemi e prospettive di ricerca (Quaderni dei seminari romani di cultura greca 1) (Rome) $127-37$

Matthaios, S. (2018) 'Eratosthenes, Crates and Aristarchus on the Homeric dual: rethinking the origins of the "analogy vs. anomaly controversy", in M. Ercoles, L. Pagani, F. Pontani and G. Ucciardello (eds), Approaches to Greek Poetry: Homer, Hesiod, Pindar, and Aeschylus in Ancient Exegesis (Trends in Classics Supplement 73) (Berlin and Boston) 25-49 
Mielsch, H. (1995) 'Die Bibliothek und die Kunstsammlung der Könige von Pergamon', AA 4, 765-79 Mirón, D. (2018) 'From family to politics: Queen Apollonis as agent of dynastic/political loyalty', in C. Dunn and E.D. Carney (eds), Royal Women and Dynastic Loyalty (Cham) 31-48

Moreno, P. (1994) Scultura ellenistica (2 vols) (Rome)

Moretti, L. (1953) Iscrizioni agonistiche greche (Studi pubblicati dall'Istituto italiano per la storia antica 12) (Rome)

- (1957) Olympionikai: i vincitori negli antichi agoni olimpici (Atti della Accademia nazionale dei Lincei; Memorie, Classe di scienze morali, storiche e filologiche 8, 8.2) (Rome)

Müller, H. (1989) 'Ein neues hellenistisches Weihepigramm aus Pergamon', Chiron 19, 499-553

Nagy, G. (1998) 'The library of Pergamon as a classical model', in H. Koester (ed.), Pergamon: Citadel of the Gods: Archaeological Record, Literary Description, and Religious Development (Harvard Theological Studies 46) (Harrisburg) 185-232

Nelson, T.J. (2019) “"Most musicall, most melancholy": avian aesthetics of lament in Greek and Roman elegy', Dictynna 16, http://journals.openedition.org/dictynna/1914

- (2020) 'Nicander's Hymn to Attalus: Pergamene panegyric', CCJ 66

- (forthcoming a) 'Beating the Galatians: ideologies, analogies and allegories in Hellenistic literature and art', in A. Coşkun (ed.), Galatian Victories and Other Studies into the Agency and Identity of the Galatians in the Hellenistic and Early Roman Periods (Colloquia Antiqua 33) (Leuven)

- (forthcoming b) 'Équitation, Char', in J.-P. Guez, F. Klein, J. Peigney and É. Prioux (eds), Dictionnaire des images du poétique dans l'Antiquité (Paris)

- (forthcoming c) 'Repeating the unrepeated: allusions to Homeric hapax legomena in Archaic and Classical Greek poetry', in D. Beck (ed.), Repetition, Communication, and Meaning in the Ancient World (Orality and Literacy in the Ancient World 13; Mnemosyne Supplement) (Leiden)

- (forthcoming d) 'The Coma Stratonices: royal hair encomia and Ptolemaic-Seleucid rivalry?', in J.H. Klooster, M.A. Harder, R.F. Regtuit and G.C. Wakker (eds), Women and Power in Hellenistic Poetry (Hellenistica Groningana) (Leuven)

Novara, A. (2005) Auctor in bibliotheca: essai sur les textes préfaciels de Vitruve et une philosophie latine du livre (Bibliothèque d'études classiques 46) (Leuven, Paris and Dudley)

Nünlist, R. (1998) Poetologische Bildersprache in der frühgriechischen Dichtung (Beiträge zur Altertumskunde 101) (Stuttgart)

Onians, J. (1979) Art and Thought in the Hellenistic Age: The Greek World View 350-50 BC (London)

Page, D.L. (1981) Further Greek Epigrams (Cambridge)

Parlasca, K. (1963) 'Das pergamenische Taubenmosaik und der sogenannte Nestor-Becher', JDAI 78, 25693

Parsons, P. (1993) 'Poesia ellenistica: testi e contesti', Aevum(ant) 5, 9-19

Patterson, L.E. (2010) Kinship Myth in Ancient Greece (Austin)

Pfeiffer, R. (1949-1953) Callimachus (2 vols) (Oxford)

- (1968) History of Classical Scholarship: From the Beginnings to the End of the Hellenistic Age (Oxford)

Pollitt, J.J. (1986) Art in the Hellenistic Age (Cambridge)

Poltera, O. (2008) Simonides Lyricus: Testimonia und Fragmente: Einleitung, kritische Ausgabe, Übersetzung und Kommentar (Schweizerische Beiträge zur Altertumswissenschaft 35) (Basel)

Pomeroy, S.B. (1997) Families in Classical and Hellenistic Greece: Representations and Realities (Oxford)

Porter, J.I. (1992) 'Hermeneutic lines and circles: Aristarchus and Crates on the exegesis of Homer', in R. Lamberton and J.J. Keaney (eds), Homer's Ancient Readers: The Hermeneutics of Greek Epic's Earliest Exegetes (Princeton) 67-114

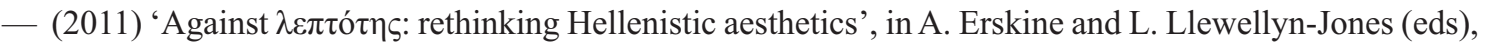
Creating a Hellenistic World (Swansea) 271-312

Primo, A. (2009) La storiografia sui Seleucidi: da Megastene a Eusebio di Cesarea (Studi ellenistici 10) (Pisa)

Prioux, É. (2007) Regards alexandrins: histoire et théorie des arts dans l'épigramme hellénistique (Hellenistica Groningana 12) (Leuven, Paris and Dudley)

- (2017) 'Géants et gigantomachies dans la poésie hellénistique', in F.-H. Massa-Pairault and C. Pouzadoux (eds), Géants et Gigantomachies entre Orient et Occident (Collection du Centre Jean Bérard 47) (Naples) 143-72 
Queyrel, F. (2003) Les portraits des Attalides: fonction et représentation (Bibliothèque des Écoles françaises d'Athènes et de Rome 308) (Athens)

Race, W.H. (1982) The Classical Priamel from Homer to Boethius (Mnemosyne Supplement 74) (Leiden) Rawles, R. (2018) Simonides the Poet: Intertextuality and Reception (Cambridge)

Robert, C. (1887) 'Beiträge zur Erklärung des pergamenischen Telephos-Frieses (I-II)', JDAI 2, 244-59

Robert, L. (1984) 'Héraclès à Pergame et une épigramme de l'Anthologie XVI,91', RPh 58, 7-18

Romano, E. (1987) La capanna e il tempio: Vitruvio o dell' architettura (Palermo)

Rusten, J. and König, J. (2014) Philostratus: Heroicus, Gymasticus, Discourses 1 and 2 (Loeb Classical Library 521) (Cambridge MA and London)

Schalles, H.-J. (1985) Untersuchungen zur Kulturpolitik der pergamenischen Herrscher im dritten Jahrhundert vor Christus (Istanbuler Forschungen 36) (Tübingen)

Scheer, T.S. (2003) 'The past in a Hellenistic present: myth and local tradition', in A. Erskine (ed.), $A$ Companion to the Hellenistic World (Oxford) 216-31

Schober, A. (1938) 'Epigonos von Pergamon und die frühpergamenische Kunst', JDAI 53, 126-49

- (1951) Die Kunst von Pergamon (Vienna)

Schultz, P. (2011) 'Style, continuity and the Hellenistic baroque', in A. Erskine and L. Llewellyn-Jones (eds), Creating a Hellenistic World (Swansea) 313-44

Schweizer, E. (1898) Grammatik der pergamenischen Inschriften: Beiträge zur Laut- und Flexionslehre der gemeingriechischen Sprache (Berlin)

Sens, A. (2004) 'Doricisms in the new and old Posidippus', in B. Acosta-Hughes, E. Kosmetatou and M. Baumbach (eds), Labored in Papyrus Leaves: Perspectives on an Epigram Collection Attributed to Posidippus (P. Mil. Vogl. VIII 309) (Cambridge MA and London) 65-83

- (2011) Asclepiades of Samos: Epigrams and Fragments (Oxford)

Slings, S.R. (1993) 'Hermesianax and the tattoo elegy (P.Brux. inv. E 8934 and P.Sorb. inv. 2254)', ZPE 98, 29-37

Snell, B. (corrected and augmented by R. Kannicht) (1986) Tragicorum Graecorum Fragmenta 1: Didascaliae Tragicae, Catalogi Tragicorum et Tragoediarum, Testimonia et Fragmenta Tragicorum Minorum (Göttingen)

Squire, M. (2011) The Iliad in a Nutshell: Visualizing Epic on the Tabulae Iliacae (Cambridge)

Stephens, S.A. (2003) Seeing Double: Intercultural Poetics in Ptolemaic Alexandria (Hellenistic Culture and Society 37) (Berkeley, Los Angeles and London)

- (2018) The Poets of Alexandria (London)

- (2019) 'Celebrating the games', in J.H. Klooster, M.A. Harder, R.F. Regtuit and G.C. Wakker (eds), Callimachus Revisited: New Perspectives in Callimachean Scholarship (Hellenistica Groningana 24) (Leuven, Paris and Bristol CT) 351-67

Stewart, A.F. (1993) 'Narration and allusion in the Hellenistic baroque', in P.J. Holliday (ed.), Narrative and Event in Ancient Art (Cambridge) 130-74

- (2006) 'Baroque classics: the tragic Muse and the exemplum', in J.I. Porter (ed.), Classical Pasts: The Classical Traditions of Greece and Rome (Princeton) 127-70

- (2014) Art in the Hellenistic World: An Introduction (Cambridge)

Strootman, R. (2010) 'Literature and the kings', in J.J. Clauss and M. Cuypers (eds), A Companion to Hellenistic Literature (Oxford) 30-45

Tarán, S.L. (1979) The Art of Variation in the Hellenistic Epigram (Columbia Studies in the Classical Tradition 9) (Leiden)

Thimme, D. (1946) 'The masters of the Pergamon Gigantomachy', AJA 50, 345-57

Tomlinson, R.A. (1972) Argos and the Argolid: From the End of the Bronze Age to the Roman Occupation (London)

Touwaide, A. (1991) 'Nicandre, de la science à la poésie: contribution à l'exégèse de la poésie médicale grecque', Aevum(ant) 65, 65-101

van Bremen, R. (2007) 'The entire house is full of crowns: Hellenistic agōnes and the commemoration of victory', in S. Hornblower and C. Morgan (eds), Pindar's Poetry, Patrons, and Festivals: From Archaic Greece to the Roman Empire (Oxford) 345-75

Visscher, M.S. (2017) 'Imperial Asia: past and present in Callimachus' Lock of Berenike', in M.A. Harder, R.F. Regtuit and G.C. Wakker (eds), Past and Present in Hellenistic Poetry (Hellenistica Groningana 21) (Leuven, Paris and Bristol CT) 211-32 
- (2019) 'Poets and politics: Antiochos the Great, Hegesianax and the war with Rome', in A. Coşkun and D. Engels (eds), Rome and the Seleukid East: Selected Papers from Seleukid Study Day V, Brussels, $21-$ 23 August 2015 (Collection Latomus 360) (Brussels) 61-85

- (2020) Beyond Alexandria: Literature and Empire in the Seleucid World (Oxford)

Voigt, E.-M. (1971) Sappho et Alcaeus: fragmenta (Amsterdam)

von der Mühll, P. (1956) 'Die Gedichte des Philosophen Arkesilaos', in Studi in onore di Ugo Enrico Paoli (Pubblicazioni della Università degli studi di Firenze, Facoltà di lettere e filosofia 4.1) (Florence) 71724

Wendel, C. (1914) Scholia in Theocritum vetera (Leipzig)

Willi, A. (2012) “"We speak Peloponnesian”: tradition and linguistic identity in post-Classical Sicilian literature', in O. Tribulato (ed.), Language and Linguistic Contact in Ancient Sicily (Cambridge) 265-88

Wright, M.E. (2016) The Lost Plays of Greek Tragedy 1: Neglected Authors (London)

Zanker, G. (1983) 'The nature and origin of realism in Alexandrian poetry', $A \& A$ 29, 125-45

- (2015) 'The contexts and experience of poetry and art in the Hellenistic world', in P. Destrée and P. Murray (eds), A Companion to Ancient Aesthetics (Chichester) 47-67

Ziegler, K. (1966) Das hellenistische Epos: ein vergessenes Kapitel griechischer Dichtung (2nd edition) (Leipzig)

- (1988) L'epos ellenistico: un capitolo dimenticato della poesia greca, a cura di Francesco De Martino, con premesse di Marco Fantuzzi (Bari) 